\title{
أثر الؤية التوحيدية في رسم ملامح الإنسان عند \\ علي شريعتي وعلي عزت بيجوفيتش
}

حنان فيض الله الحسيني

الملخص

يكشف البحث عن ملامح الرؤية التوحيدية، ومعالم بناء الإنسان في الفكر الإسلامي المعاصر، وَفقاً لتصوُر اثنين

من مُفكِّري المدرسة التوحيدية: علي شريعتي، وعلي عزت بيجوفيتش، وذلك بتحديد الأُسس المعرفية التي قامت عليها

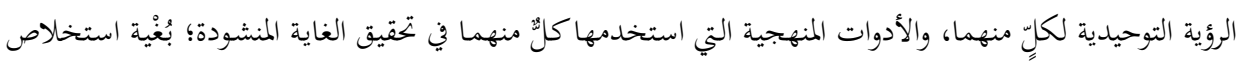

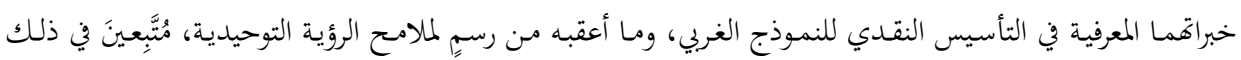

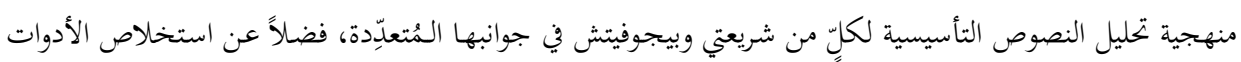

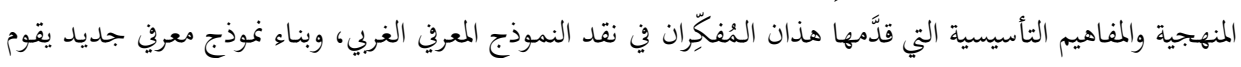
على أساس التوحيد.

الكلمات المفتاحية: الرؤية التوحيدية، النموذج الغربي، طبيعة الإنسان، الطبيعة الثنائية، الفلسفات الغربية.

\section{The Impact of the Tawhidi Perspective in the Characterization of Man as Perceived by Ali Shariati and Ali Izzat Begovic}

\section{Hanan Al-Husaini}

\begin{abstract}
This paper reveals the features of the Tawhidi perspective and the parameters of Man's image in contemporary Islamic thought, as perceived by two Tawhidi school thinkers: Ali Shariati and Ali Izzat Begovic. We carried out the study by identifying the epistemological bases on which the Tawhidi perspective and the methodological tools of each were based and utilized in achieving the desired goal; in order to extract their epistemological experiences in criticizing the Western epistemological model, and establishing a new model founded on Tawhid.
\end{abstract}

Keywords: Tawhidi (monotheistic) perspective, Western epistemological model, Human nature, Dualistic nature, Western philosophies.

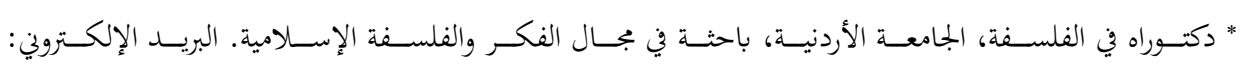
hanan_alhuss@yahoo.com تم تسلم البحث بتاريخ 2018/2/10م، وقُبل للنشر بتاريخ 2018/9/3م. 
مقدمة:

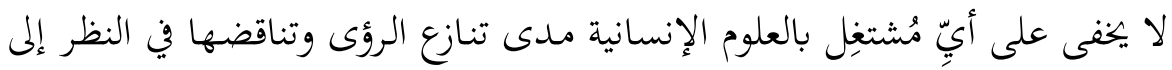

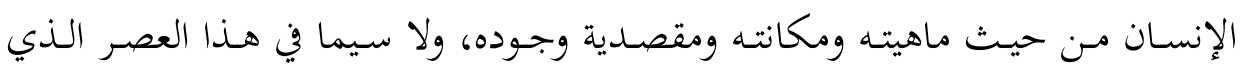

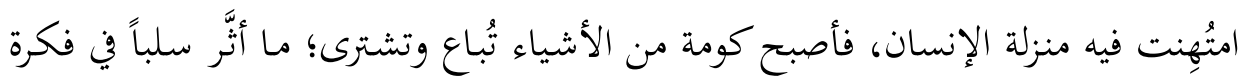

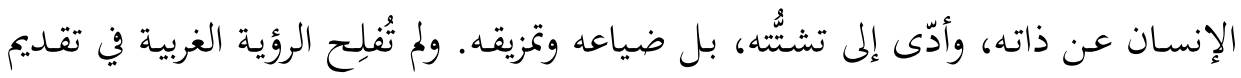

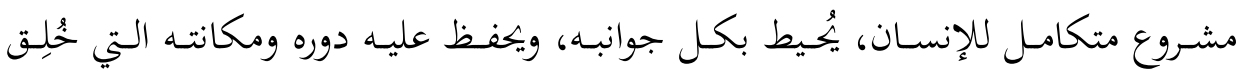

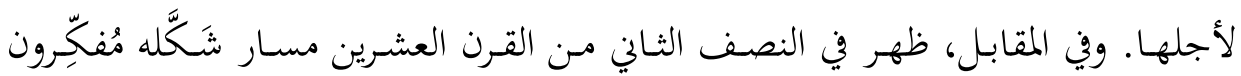

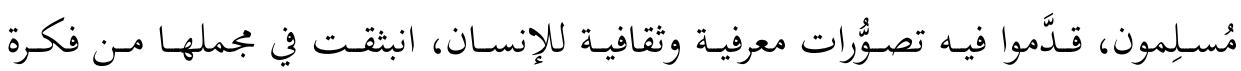

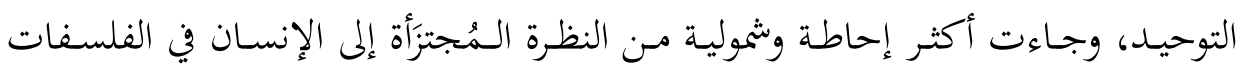

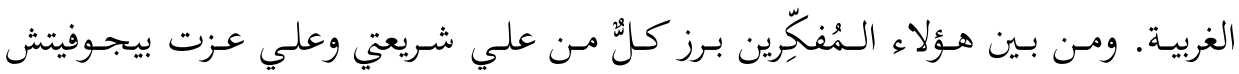

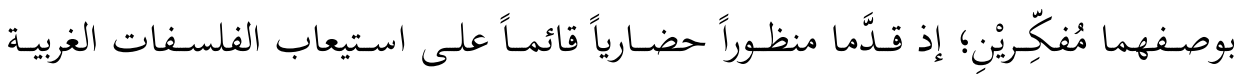

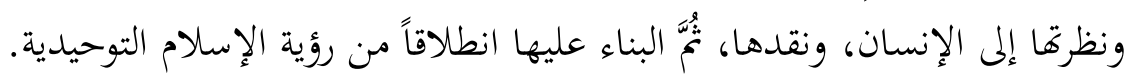

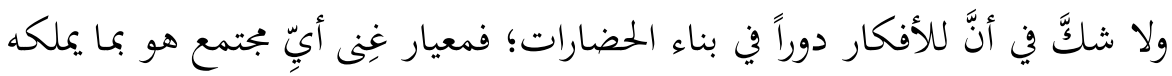

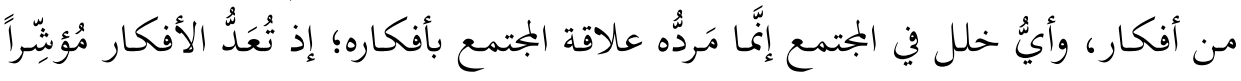

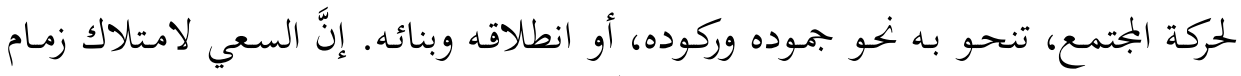

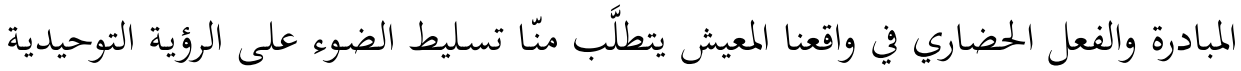

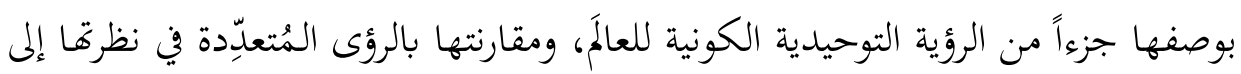

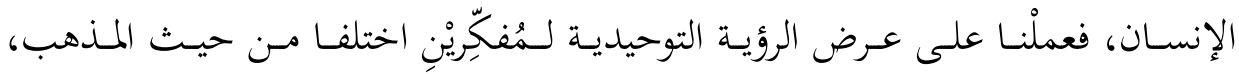

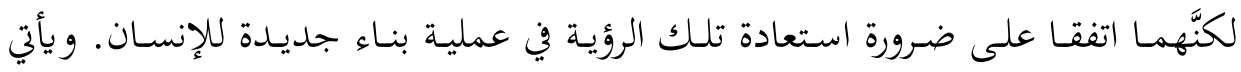

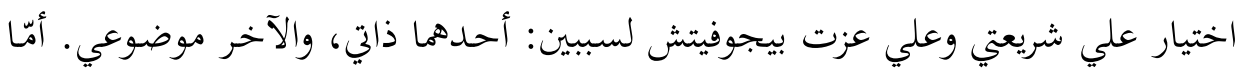

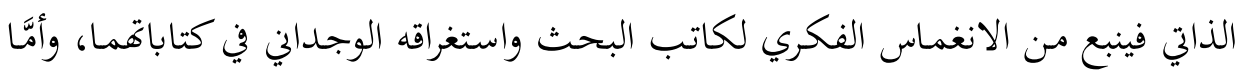

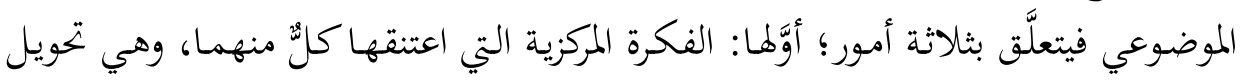

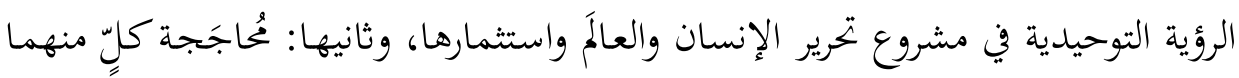

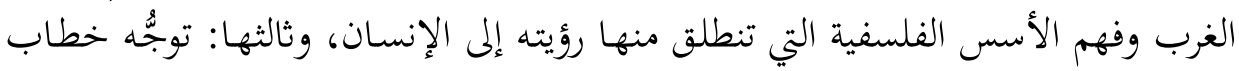
كلِ منهما إلى الشرق والغرب معاً. 
وقـد استطاع شـريعتي وبيجـوفيتش، في نصوصهمما الـمُتعلِّدة المنثـورة في مـاكتبـاه، تأسيس رؤية ناهضة بالإنسان تقوم على قراءة جديدة للفكر الغربي، أساسها الانفتاح

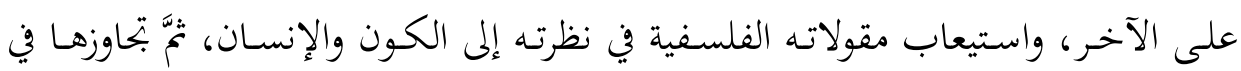
سبيل بناء حضاري جديد، تظهر فيه ملامح الرؤية التوحيدية وبحلِّياتِا في الإنسان. فمَن علي شريعتي، 1 وعلي عزت بيجوفيتش؟. من الدراسات السابقة التي تناولت الإنسان من خلال الرؤيتين: التوحيدية والغربية، دراسة عبد الحميد أحمد أبو سليمان في كتابه "الإنسان بين شريعتين"، التي تحدَّث فيها عن طبيعة الإنسـان وَفق الرؤية القرآنيـة، فوصفها بالطبيعة الثنائيـة التي تتكوَّن مـن نور

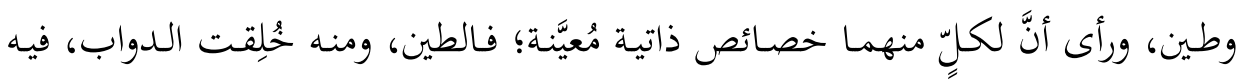

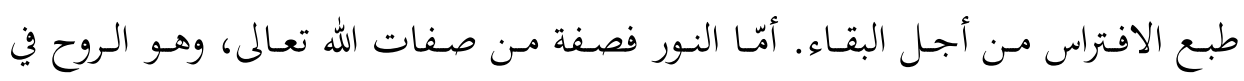
الإنسان التي تحمل صفة الخخير والحقق والهداية. والإنسان هو المخلوق الوحيد -مـن بين المخلوقات التي تدبُّ على الأرض - الذي هداه الله إلى شريعة النور، التي جعلها مُتمايزة

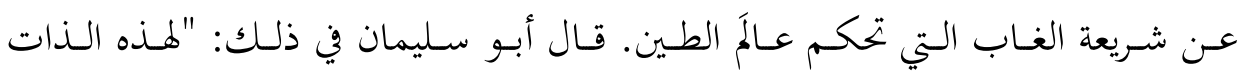
الإنسانية المزدوجة تكوين وطبيعة وغاية وقانون يختلف كل الاختلاف عن تكوين الحيوان

1 علي شريعتي (1921-1986م) هو مَعْلم أساسي من معالمُ النهضة الإيرانية، وأبوه محمد تقي شريعتي كان من كبار

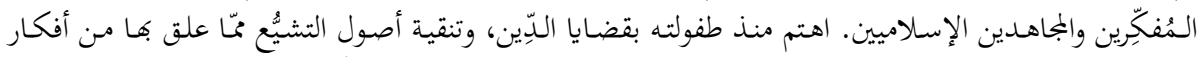

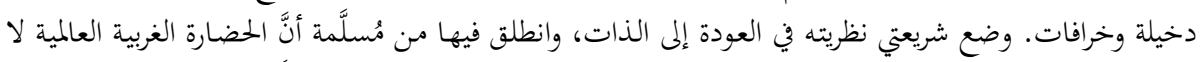

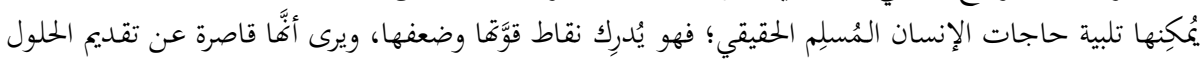

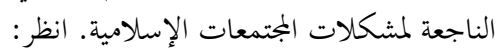

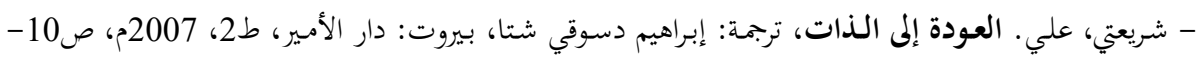

2 علي عزت بيجوفيتش (1925-2003م). مفكر وفيلسوف إسلامي وزعيم سياسي بوسني، اختير رئيساً لجمهورية

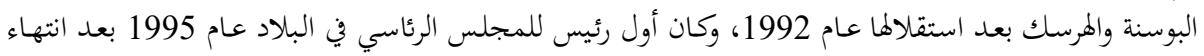

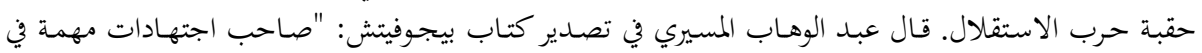

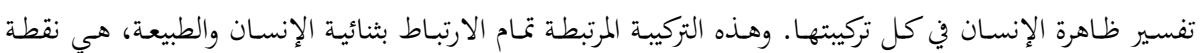

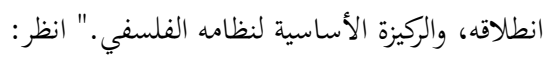
- بيجوفيتش، علي عزت. الإسلام بين الشرق والغرب، ترجمة: محمد يوسف الأف عدس، القاهرة: دار الشروق، ط4،

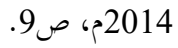




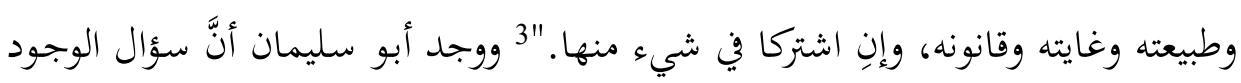

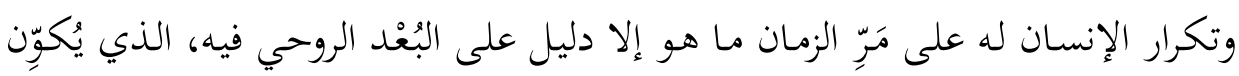

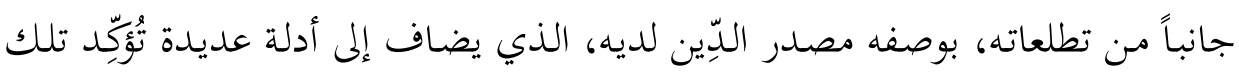
الحقيقة.

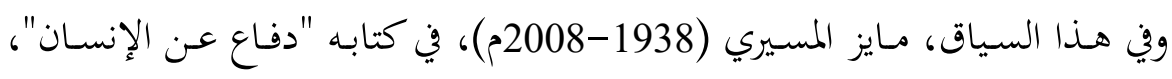

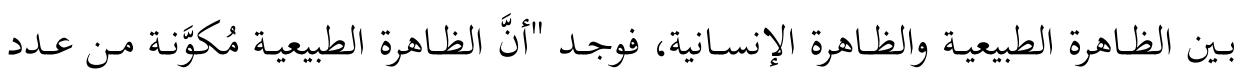

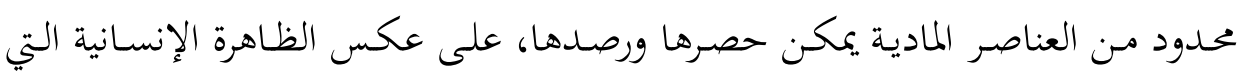

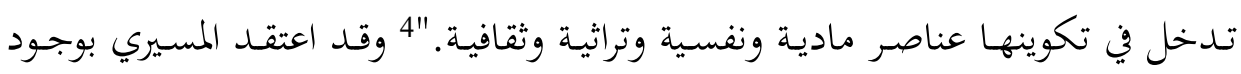

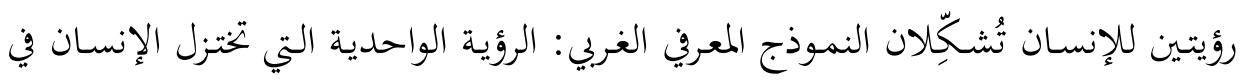

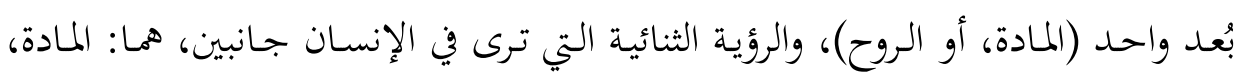

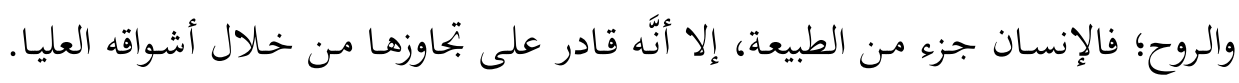

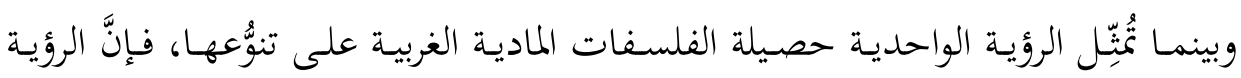

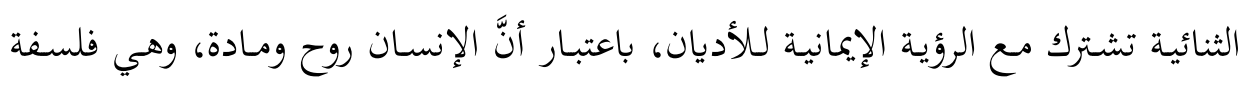
ظهرت في الغرب، وتمركزت حول الإنسان، وسمِّميت الرؤية الإنسانية الهيومانية.

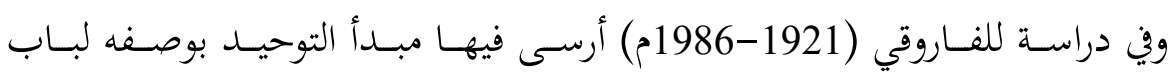

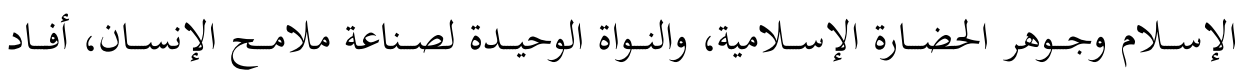

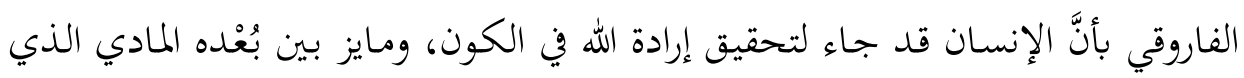

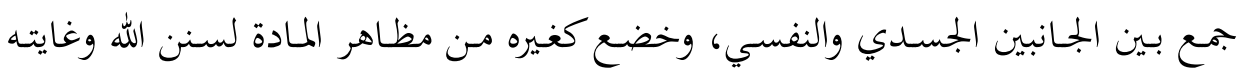

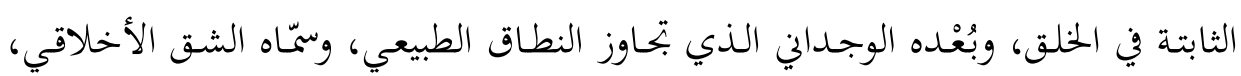

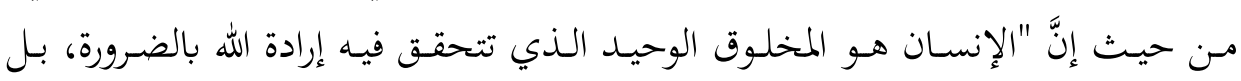

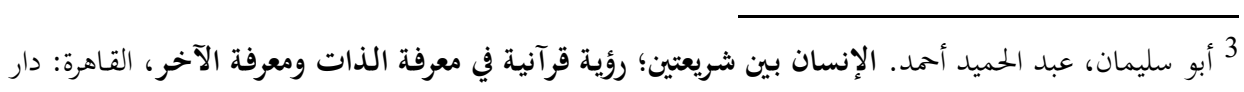

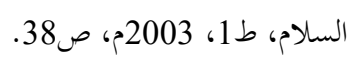
4 المسيري، عبد الوهاب. "دفاع عن الإنسان" دراسات نظرية وتطبيقية في النماذج المركبة، القاهرة: دار الشروق،

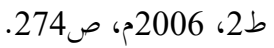

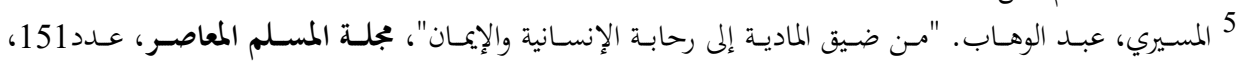

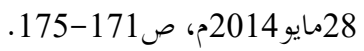




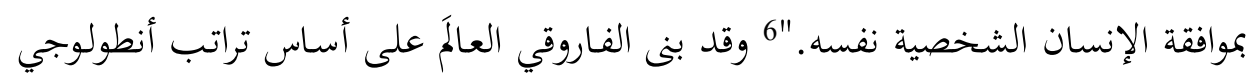

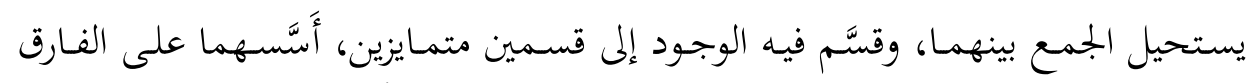

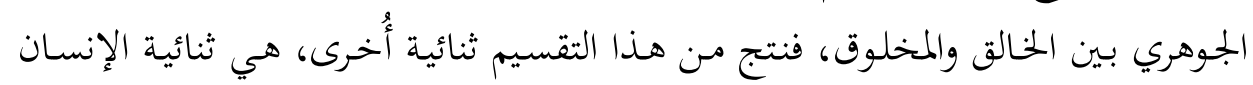

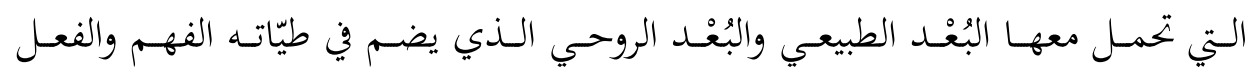
الأخلاقي للإنسان. وبناءً على ما تقدَّم، فقد حاول البحث الإجابة عن ثلاثة أسئلة أساسية تتلاقى مع

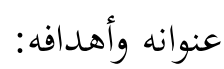
ما الإطار المرجعي الذي يستند إليه علي عزت بيجوفيتش وعلي شريعتي في استلهام

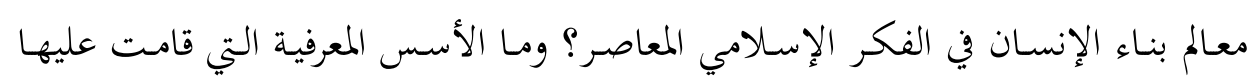

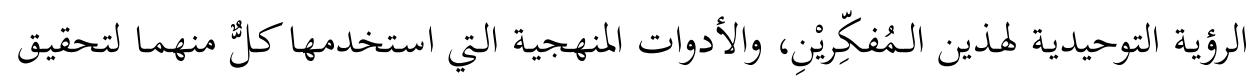

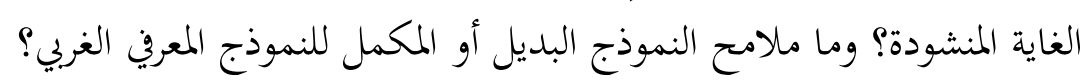

أولاً: الإطار المرجعي لبناء معالم الإنسان في الفكر الإسلامي المعاصر

\section{1. الخصائص الإبستمولوجية للؤية التوحيدية:}

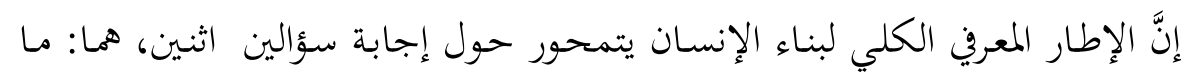

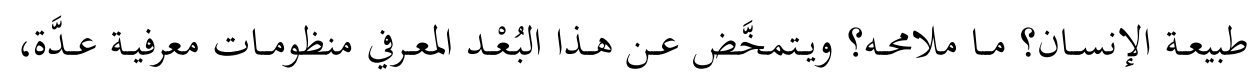

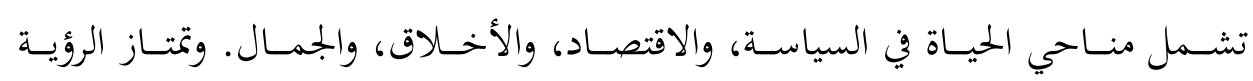

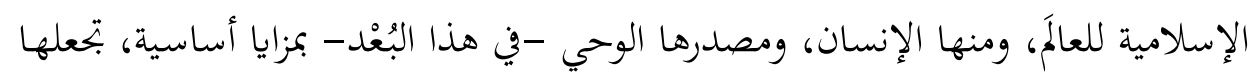

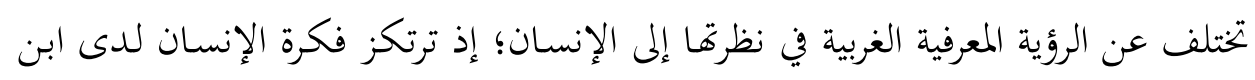

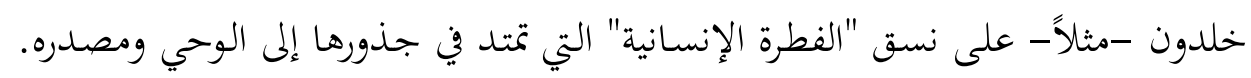

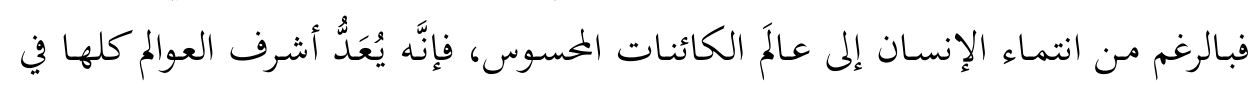

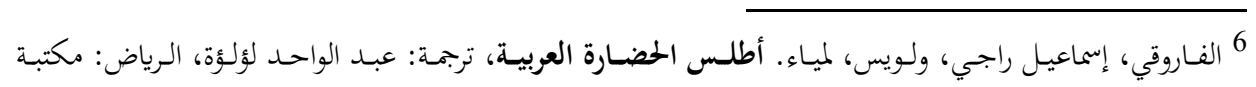

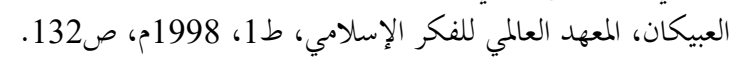

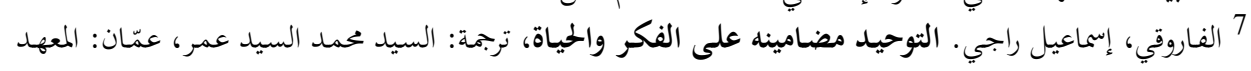
العالمي للفكر الإسلامي، ط1اجي، 2016م. النوحيد مضامينة 


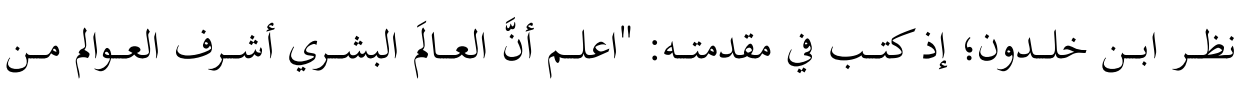

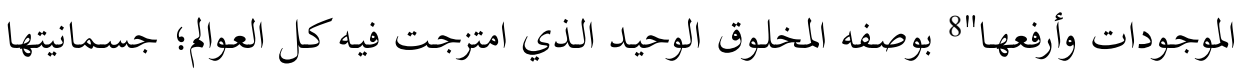

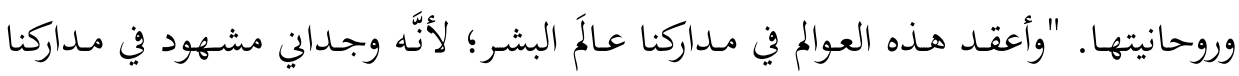

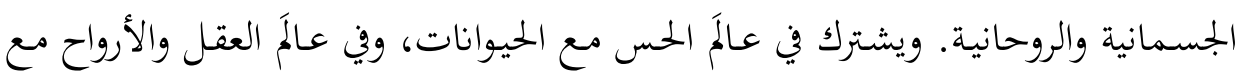

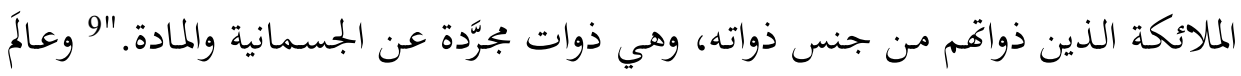

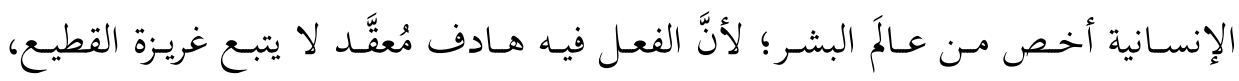

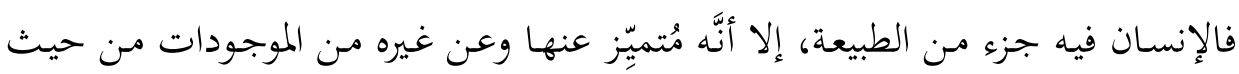

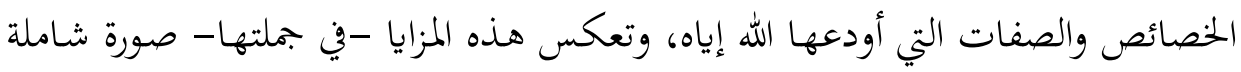
متكاملة عن أبعاد الإنسان الروحية والمادية.

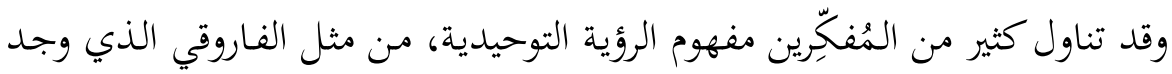

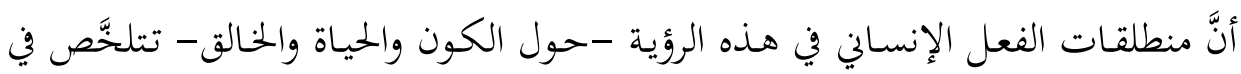

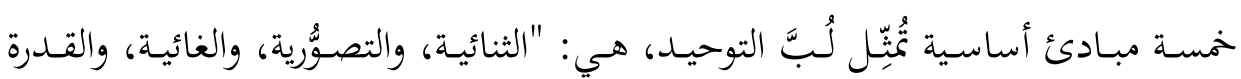

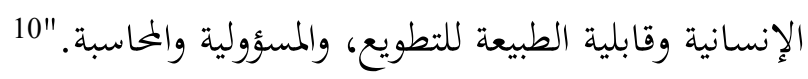

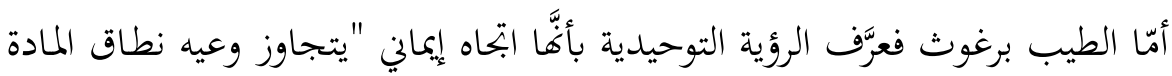

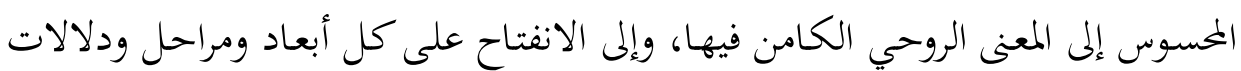

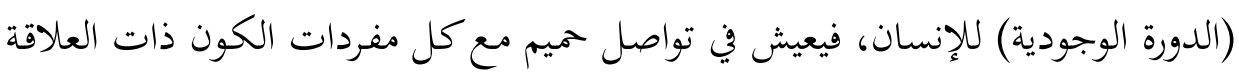

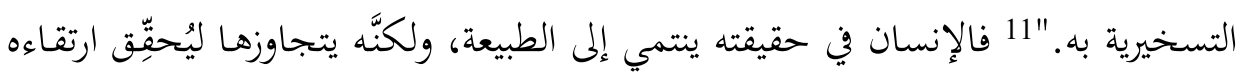

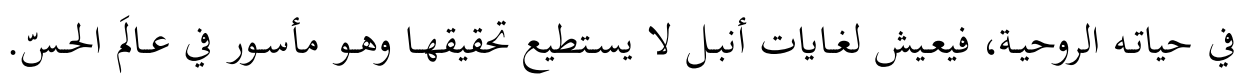

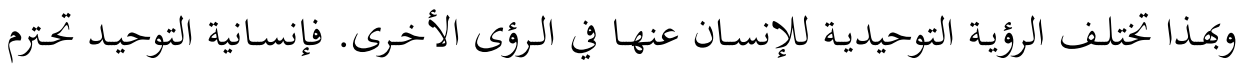

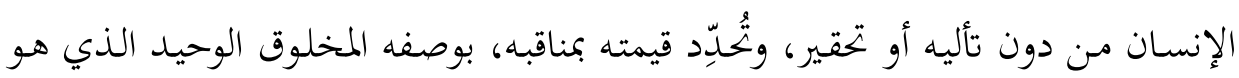

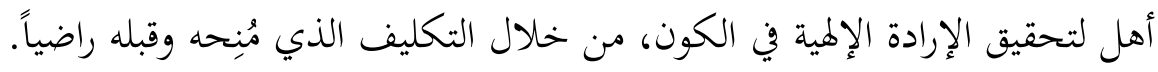

$$
\begin{aligned}
& 8 \text { ابن خلدون، عبد الرحمن. المقدمة، بيروت: دار الكتب العلمية، ط1، 2000م، ص378-379. } \\
& 9
\end{aligned}
$$

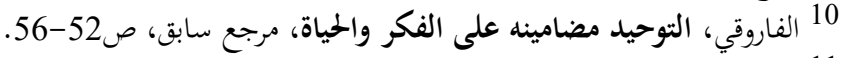

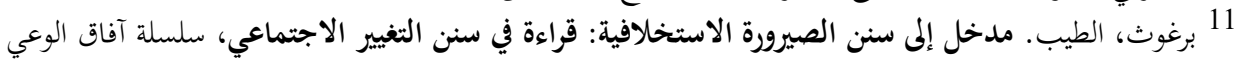

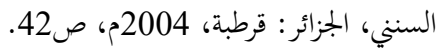




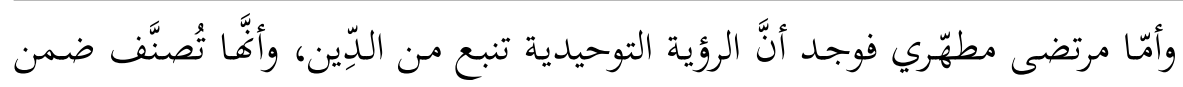

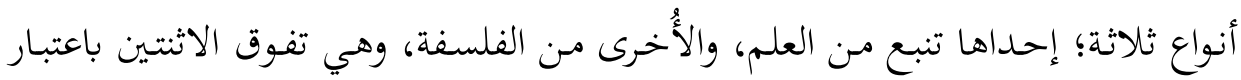

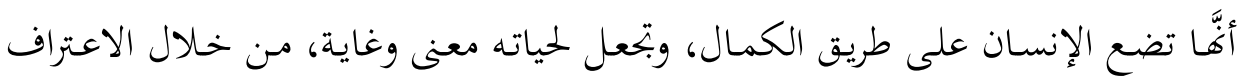

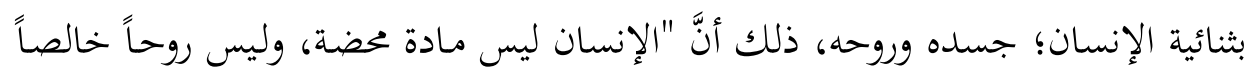

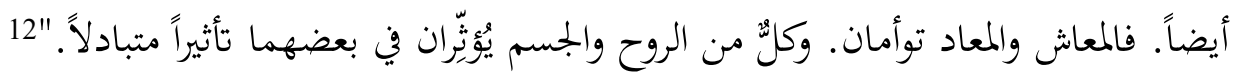

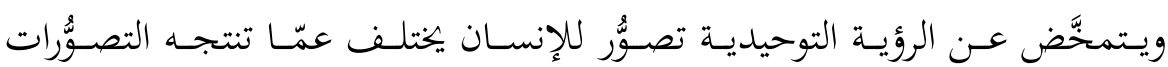

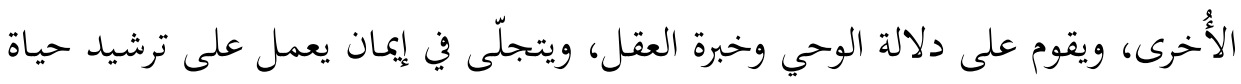
الإنسان، استناداً إلى مرجعية متعالية تتجاوز الكون والتاريخ، هي مرجعية الوحي الإلهي.

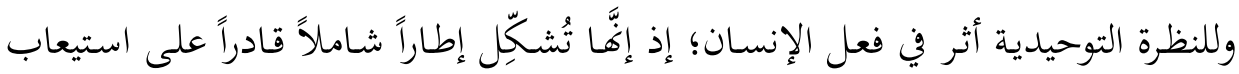

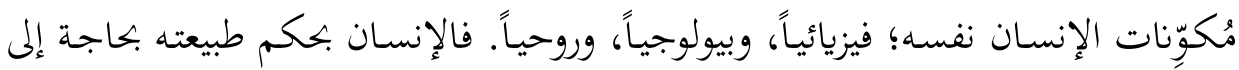

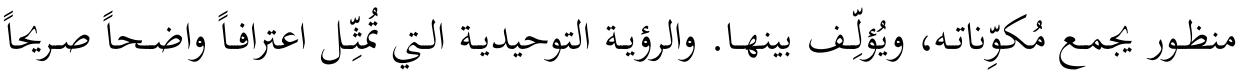
بثنائية الإنسان تحميه مـ الوقوع في جبر الطبيعة (الفلسفة المادية)، ومن استلاب وعيه وليه بالتحكُم الإلهي المطلق الذي يوقِعه في جبرية اللاهوت.

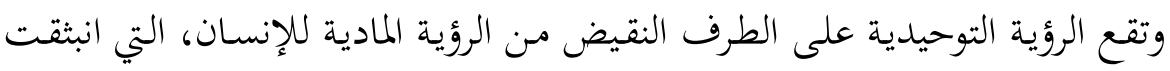

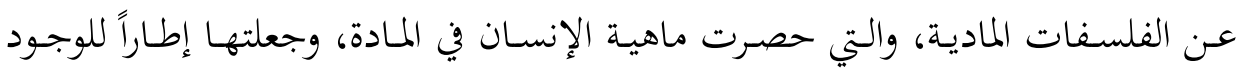

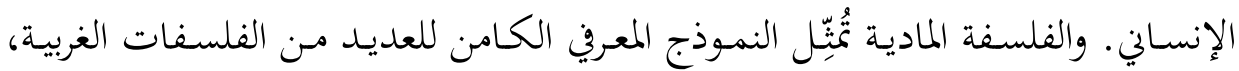

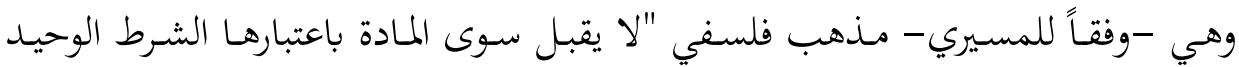

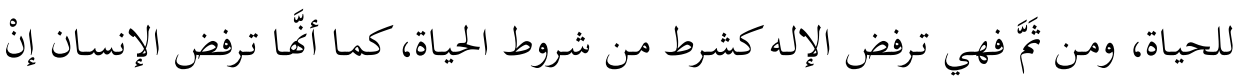

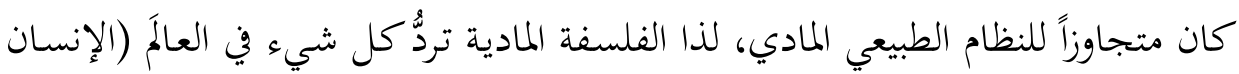

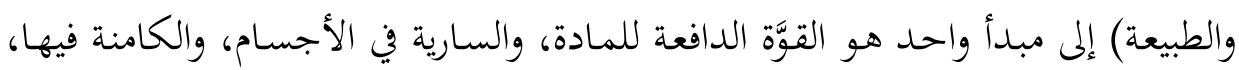

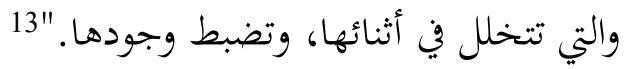
وبتحر الإشارة إلى عظمة الآثار السلبية التي تثيرها قضية احتجاب الرؤية التوحيدية

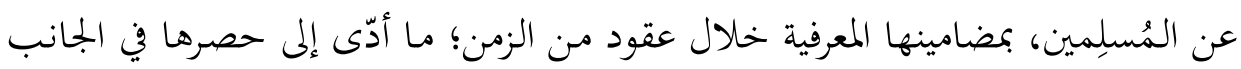

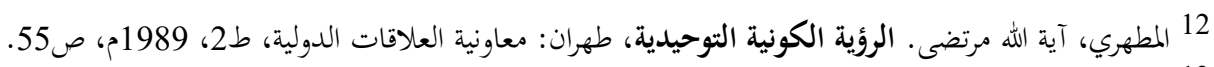

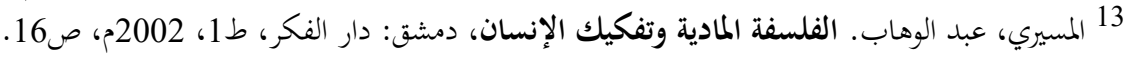


العقدي من دون بتحاوزه إلى انعكاسات هذه الرؤية في مضامين الحياة، وهو ما فتح المجال

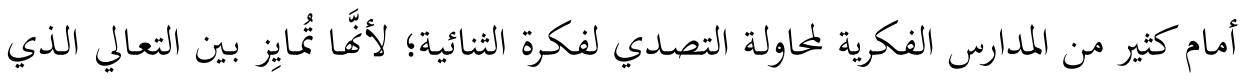

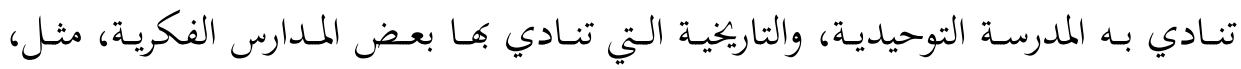
مدرسة العروي، ومدرسة أركون، وغيرهما.

\section{2. منطق التكامل بين المثاريع الغربية والمشاريع الإسلامية:}

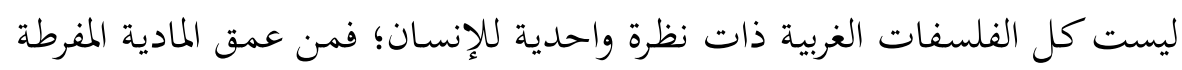

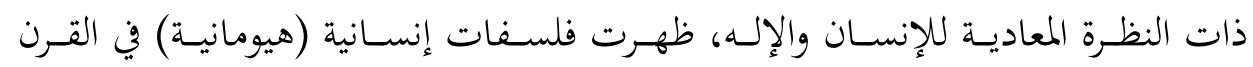

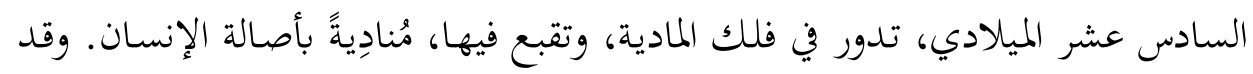

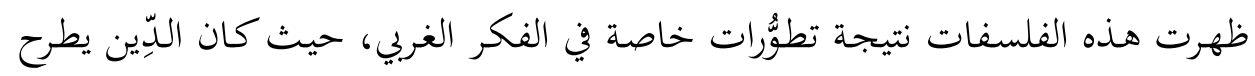

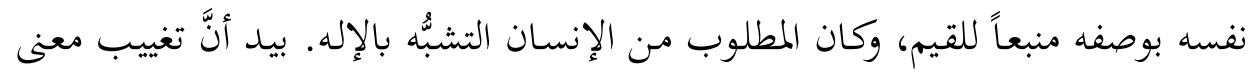

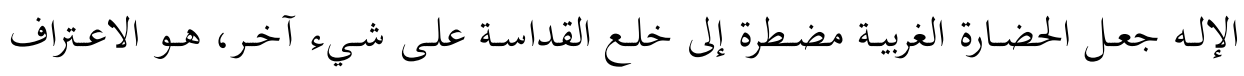
بالإنسان وأصالته في الكون.

وقـــ ظهـر نموذجـان للفلسـفة الهيومانيـة؛ الأول: يتمركـز حـول الطبيعـة، ويعـادي

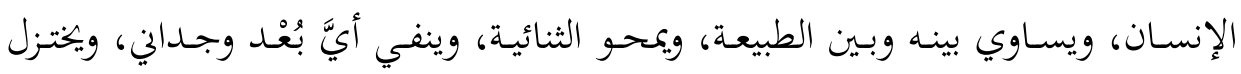

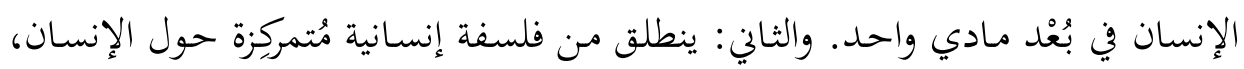

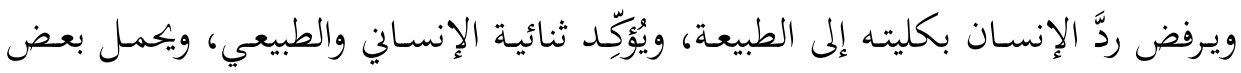

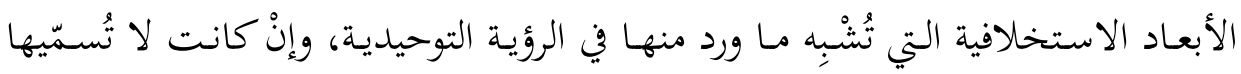

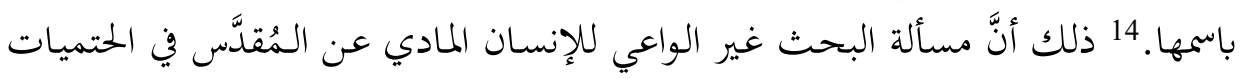

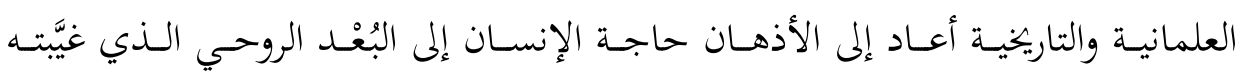

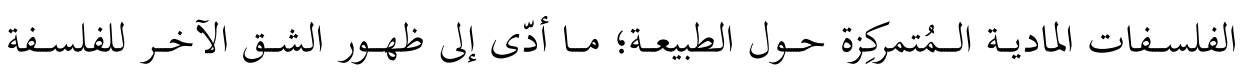

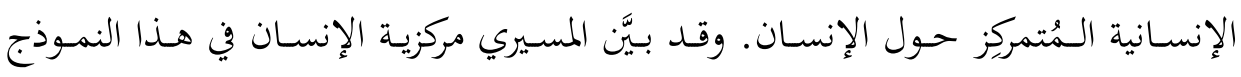

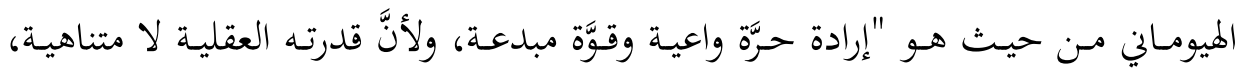

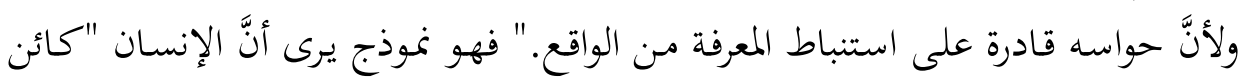

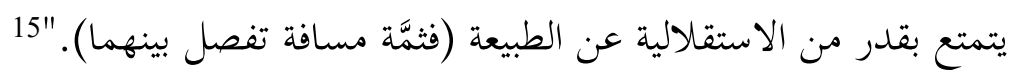
14 14 المسيري، من ضيق المادية إلى رحاب الإنسانية والإيمان، مرجع سابق. 15 المرجع السابق، صني، صيق المادية. 


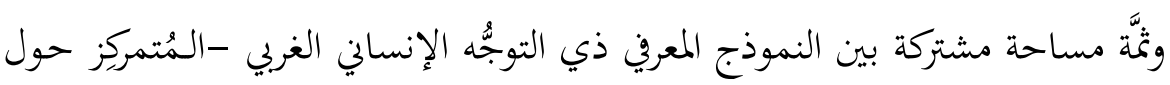

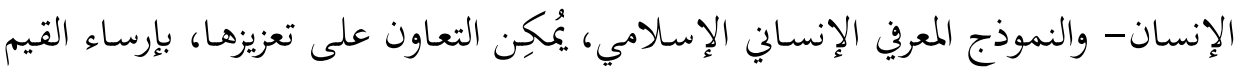

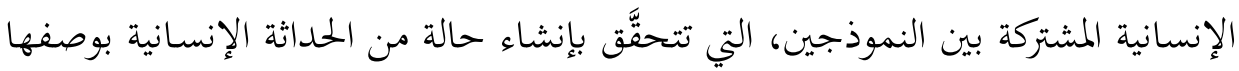
مرجعية مشتركة بينهما.

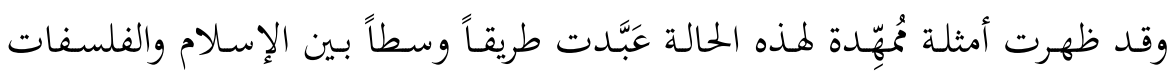

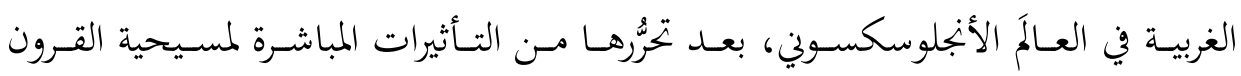
الوسطى، التي تمتَّلت في موقف روجر بيكون بوصفه مُؤَِّس هذه الثنائية؛ فقد بنى بيكون فكره الفلسفي "على قاعدتين مستقلتين في أصلهما: الخبرة الباطنية التي تؤدي إلى استنارة الروح (الدِّين)، والملاحظة التي تؤدي إلى العلم الصحيح (أو العلم التجريبي)، "16 مُؤكِدِاً

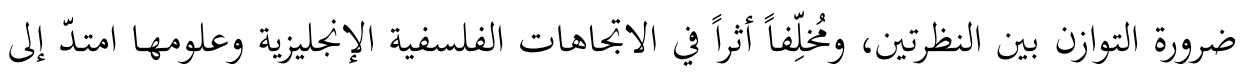
وقتنا الحاضر.

وتوجد جملة من المبادئ العامة التي تحكم مفهوم التكامل المعرفي، أشار إليها أبو بكر

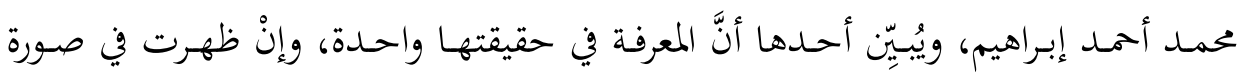
تقسيمات وبجالات مُتعلدِدة، فهي -في فاية المطاف - تقسيمات إجرائية. وتُعنى وحمدة

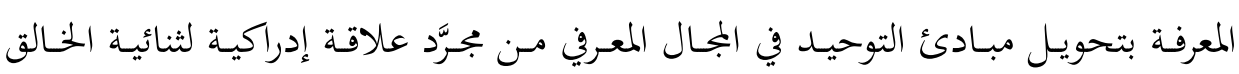
والمخلوق إلى مضامين معرفية تصل الإنسان بربه. 17

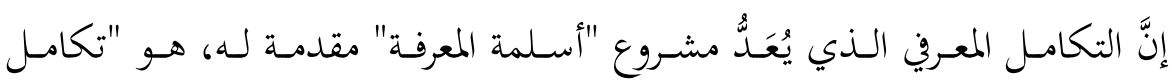

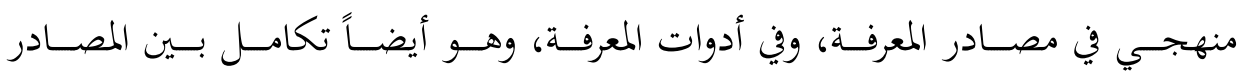

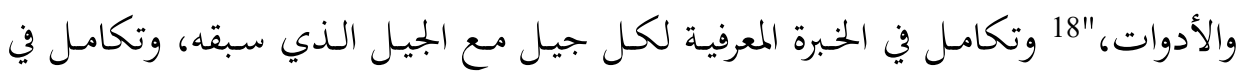

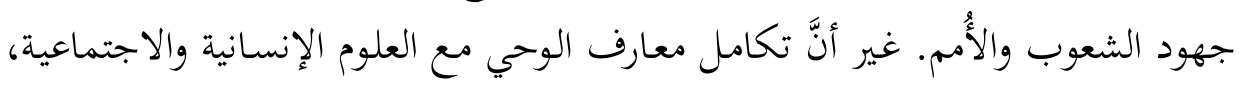

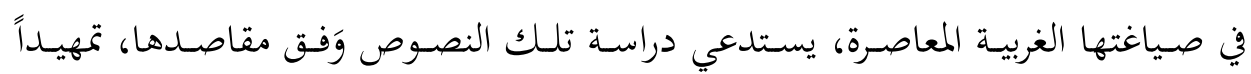

$$
16 \text { بيجوفيتش، الإسلام بين الشرق والغرب، مرجع سابق، ص352. }
$$

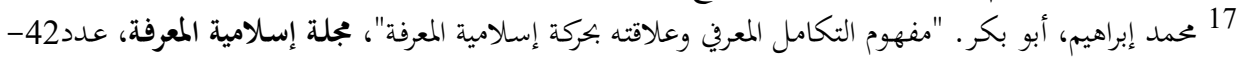

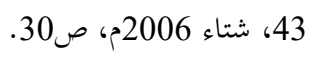

18 ملكاوي، فتحي حسن. منهجية التكامل المعرفي: مقدمات في المنهجية الإسلامية، عمّان: المعهد العالمي للفكر

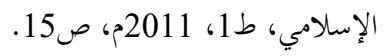




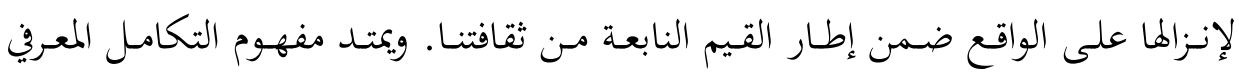

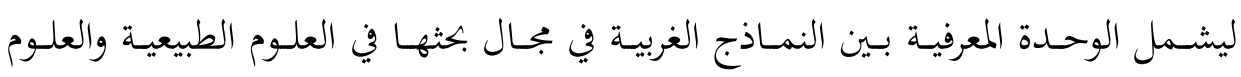

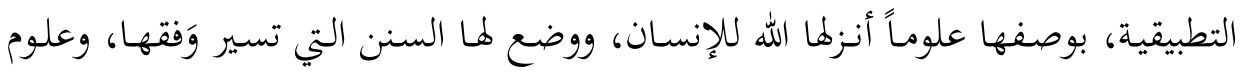

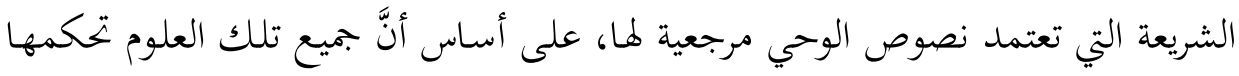
رؤية معرفية موحدة لها، تُشِّكِل الأساس المنطقي لتكاملها.

ثانياً: مدخل مفاهيمي ومنهجي للرؤية التوحيدية في نموذج علي شريعتي وعلي عزت بيجوفيتش 1. المفاهيم المفصلية في نوذج علي شريعتي ونموذج علي عزت بيجوفيتش:

$$
\text { أ. نموذج علي شريعتي: }
$$

طرح شريعتي مبدأ العودة إلى الذات الإسلامية السمتمبِّلة في الحالة الإلهية الفطرية

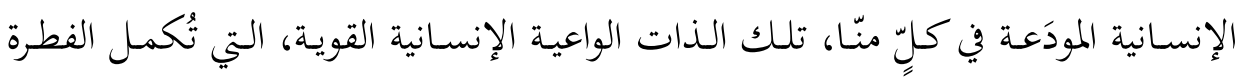

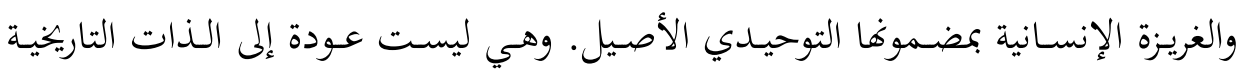

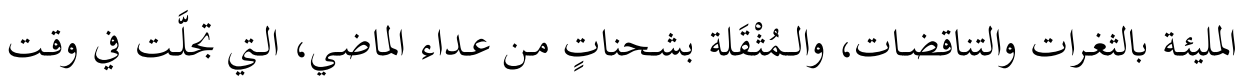
من الأوقات في الأعمال الحضارية المتعاقبة. 19 وقد استخدم شريعتي مصطلحات ابتدعها ووظَّهـا في بلورة رؤاه لمكانة الإنسـان وموقعه في الرؤية التوحيدية، منها:

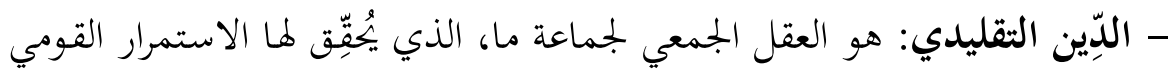

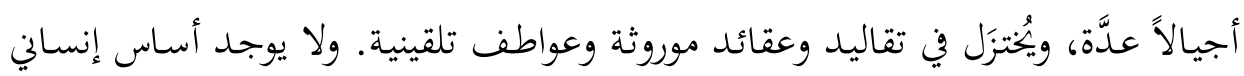

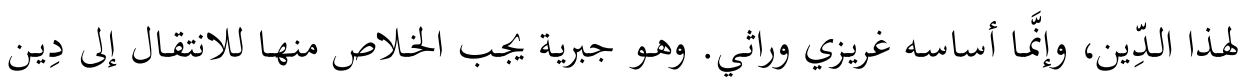


- الدِّين الأيديولوجي: هو "عقيدة منتخبة بصورة واعية، "20 بدأ الأنبياء بنشرها، وأوجدوا بها هضة ووعياً.

- اللدِّين التبريـري: هـو دِيـن يقوم على تبريـر الوضـع القـائم، بكيـث ينحـر الحريـة، ويُيْيَف الوعي، ويُناصِر الأنظمة. - الدِّين الثوري: هو دِين ينماز برؤية نقدية بتحاه الواقع، ببُعْديه: المادي والمعنوي، ويسعى إلى تغييره في حال لم يتوافق مع دِين التوحيد.

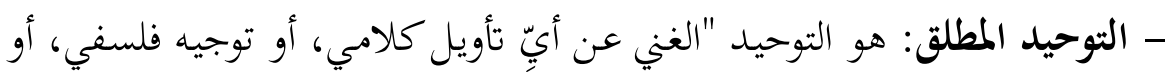
سفاسف وسفسطة"21 جنحت لها الأديان السابقة. - الصنمية الدينية: هي الانقياد للتعاليم الدينية وتنفيذها من دون تفكير.

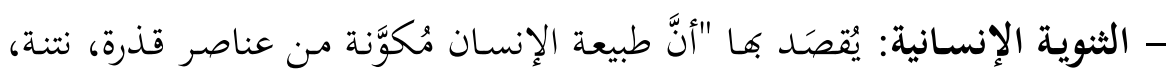

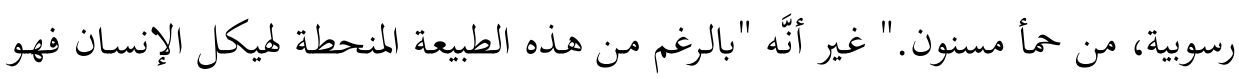

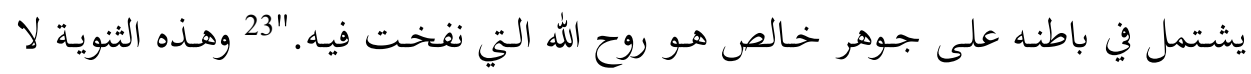

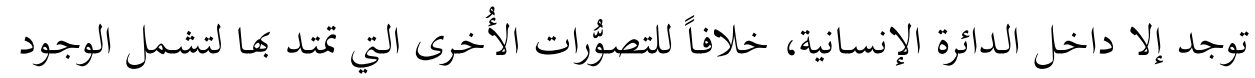
كاملاً. - أصالة الإنسان المتعالية:24 هي أصالة ناجمة عن التوحيد، ووصفها بالمتعالية إنَّا

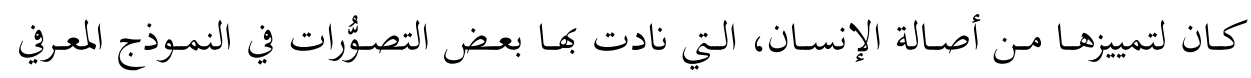
- التكامل البشـي: هو الوصول بالإنسـان إلى حالة التخلُّص من جبرية سـونه الأربعة، فيصبح شبيهاً لله من حيث حرية الاختيار والإرادة.

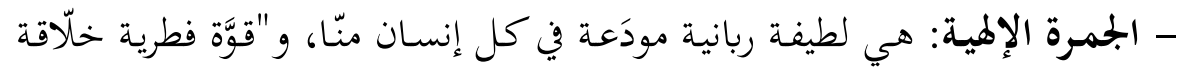
كامنة في ذواتنا. "25

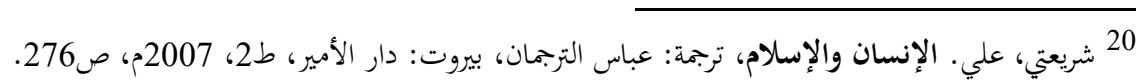

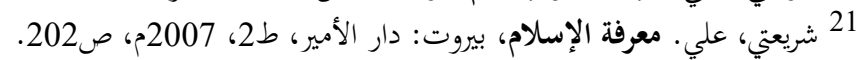

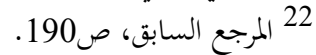

$$
\begin{aligned}
& 23 \text { المرجع السابق، صلمانق ص214-215. } \\
& 24 \text { شريعتي، علي. الإنسان والتاريخ، ترجمة: خليل علي، بيروت: دار الأمير، ط2، 2007م، ص62. } \\
& 25 \text { المرجع السابق، صنيع. الإنسان }
\end{aligned}
$$




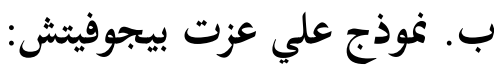

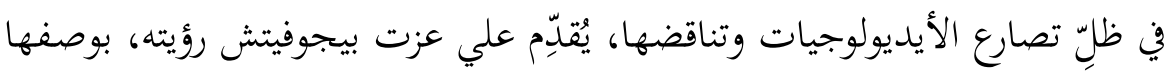

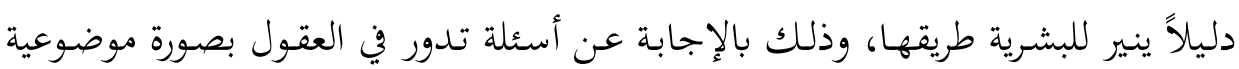

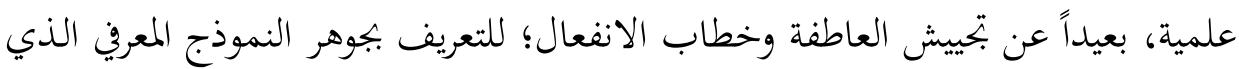

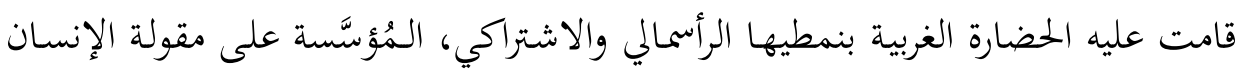

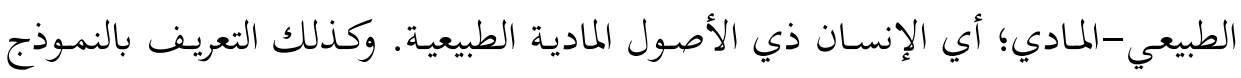

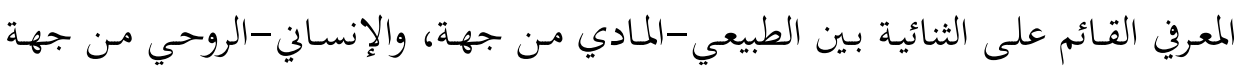

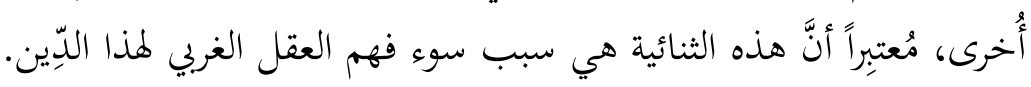

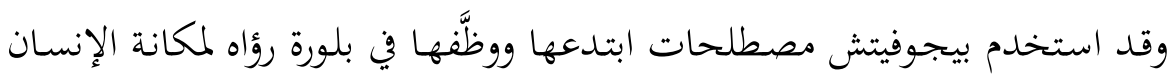
وموقعه في الرؤية التوحيدية، منها:

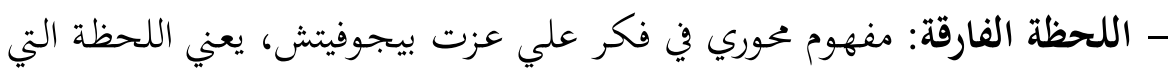

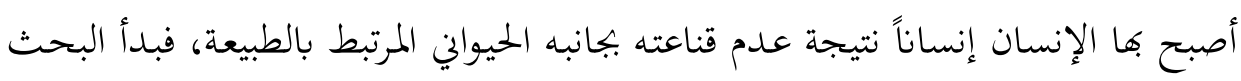
عن شيء آخر.

- الدوار الميتافيزيقي: ما أنتجته اللحظة الفارقة في كينونة الإنسان، وأدّى إلى فصل الإنسان عن عالمَ الطبيعة/ المادة.

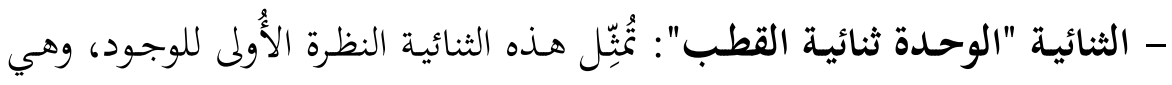

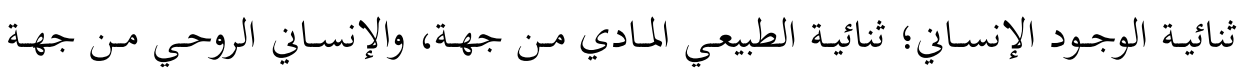

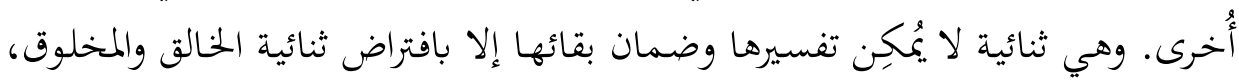

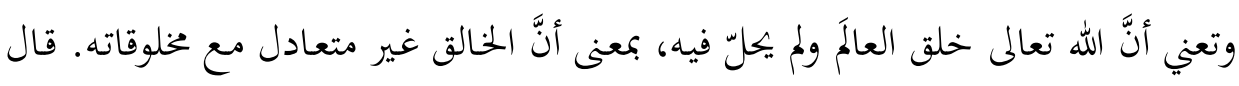

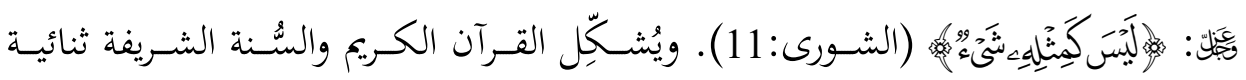

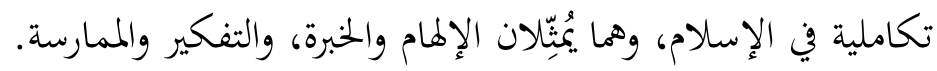

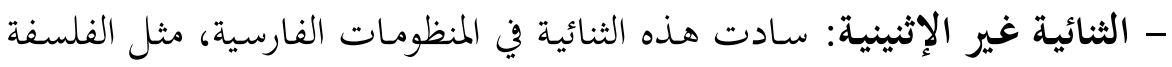

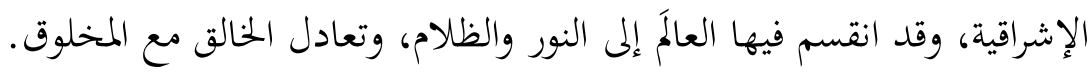

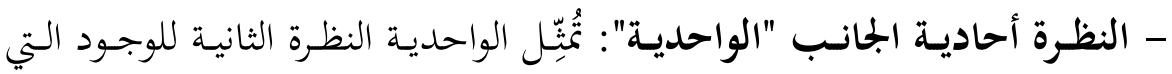

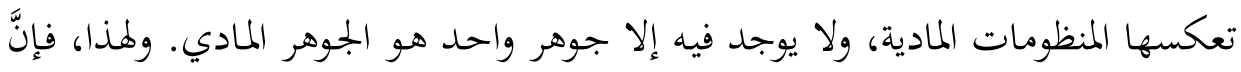




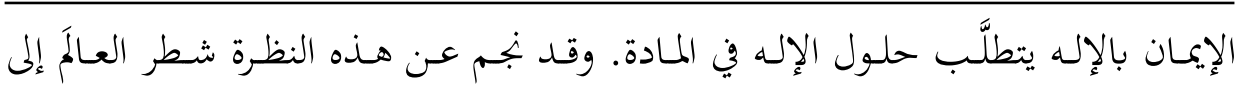
شطرين متصادمين: مادية ملحدة، وروحانية مغرقة في الأسرار، يُنكِرِ كل منهما الآخر .

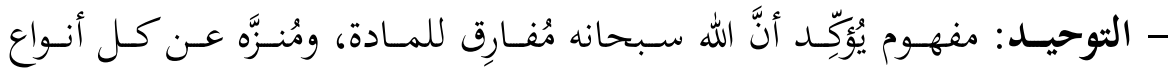
الحلولية؛ أي إنَّه مُنزَّه عن الحلول في الطبيعة كما في الماركسية، والحلول في التاريخ كما في الهيجلية.

- الدِّين الجُرَّد: دِين يدعو الإنسان إلى أنْ يحيا ليُصلِح ذاته فقط؛ فهو تعبير عن

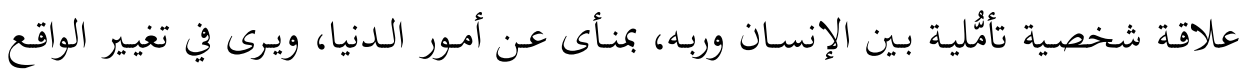
عمليةً لا طائل منها. - الدّيّن المطلق: دِين يجممع بين بُعْدين اثنين، هما: الروح وأشواقها العليا، والطبيعة وحاجتها المادية الواقعية. - الجموّابي والبرّالي: يُقصَد بذلك الروح وأشواقها، والحياة وأبعادها المادية. - الازدواجية: يُقصَد بها الجمع بين متناقضين أو متباعدين، والتوازن بينهما، وهما:

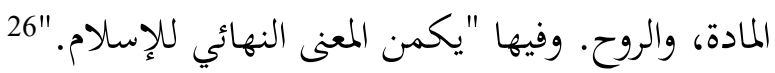

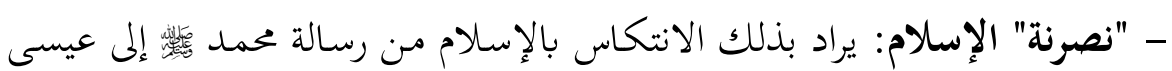

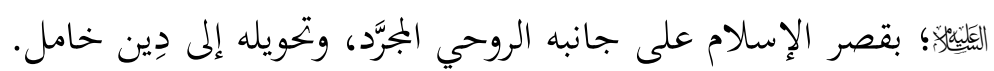

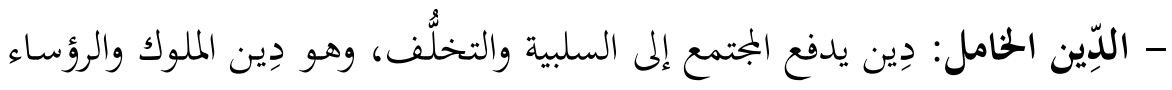
وعلماء السلطان، الذين يُشكِلون جميعاً الوجه الخارجي للانشطار الداخلي لإني لإسلام.

\section{2. المنهج عند علي شريعتي وعلي عزت بيجوفيتش:}

اتَّبع علي شريعتي منهج البحث الاجتماعي -علم التصنيف الاجتماعي - بوصفه وتئي

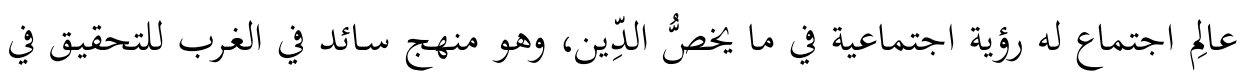

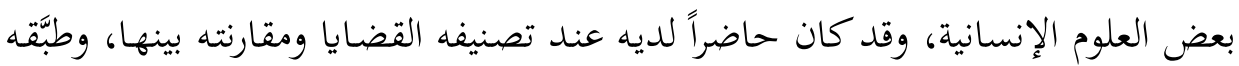

في دراسته للدّيّن، واعتمد عليه في المقارنة بين الدّّين التوحيدي والأديان الأُخرى. 27

$$
26 \text { بيجوفيتش، الإسلام بين الشرق والغرب، مرجع سابق، ص50. }
$$

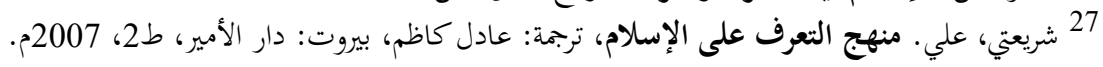


وظهـر المـنهج النقـدي في كتـابات شـريعتي قوياً صـارماً، وأفـاد منـه في نقــ الأفكار

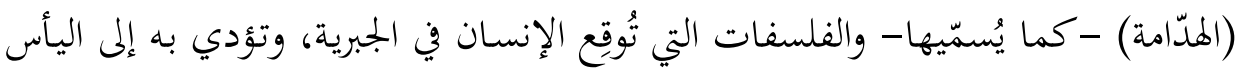

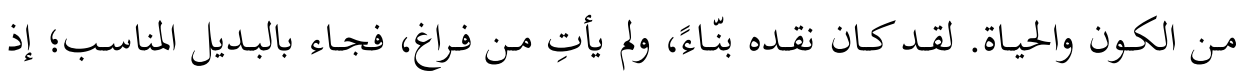

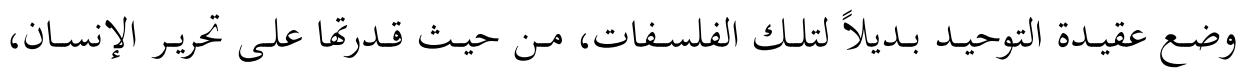

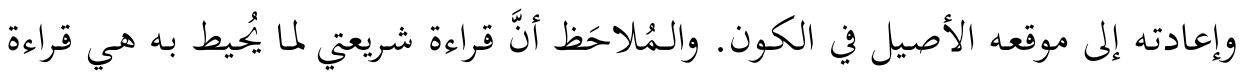

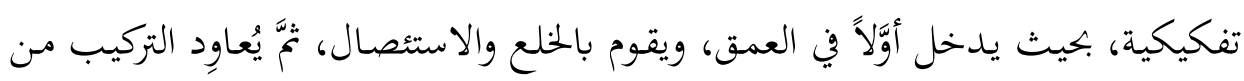
جديد وَفق رؤية جديدة يراها تُمثنّل البديل.

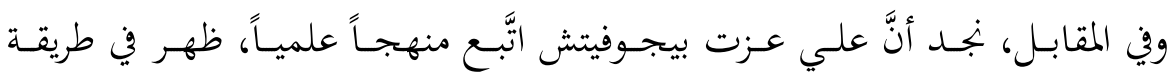

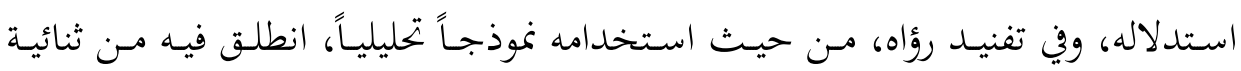
الطبيعة-المادة، في مقابل الإنسان-الإنسان الرباني، وطبَّقهه في رحلته التفكيكية التركيبية

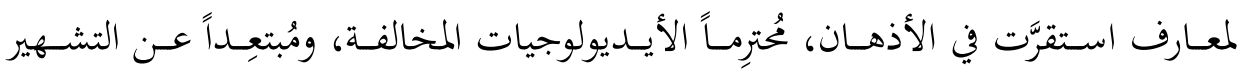

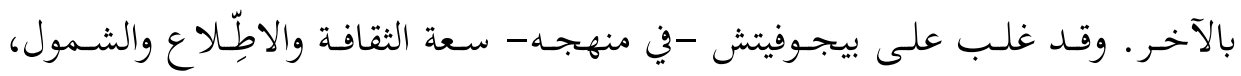

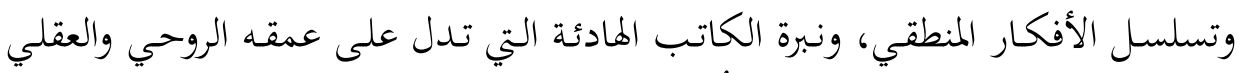

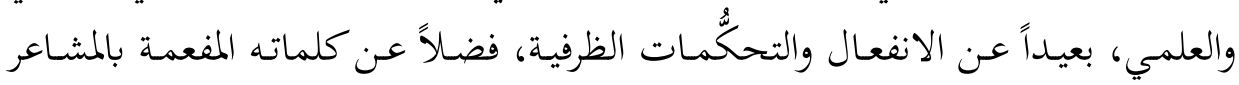
الفياضة التي لا تحمل عدائية لأحد. بعد.

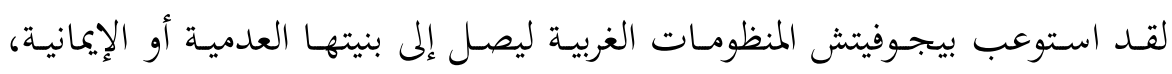

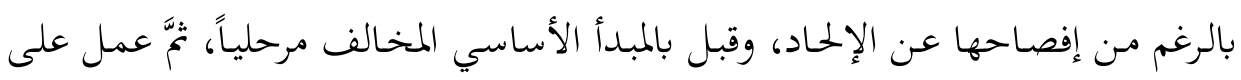

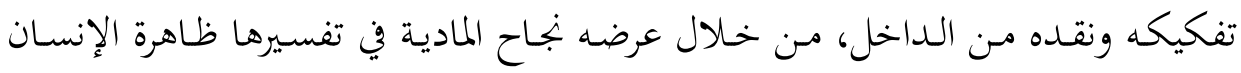

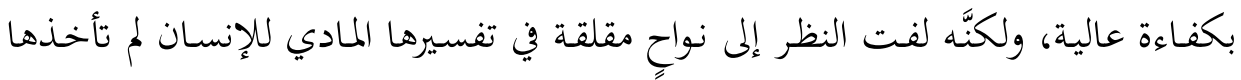

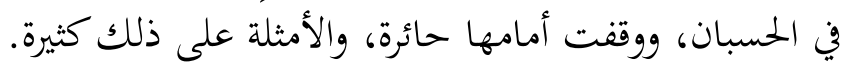
وكشف بيجوفيتش مزاعم الإلحاد والمادية عن طريق تفسير البُعْد الإنساني في ظاهرة

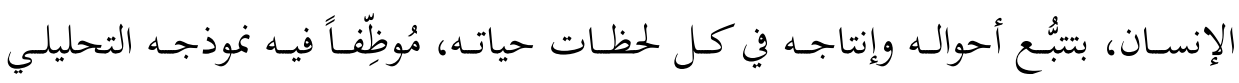

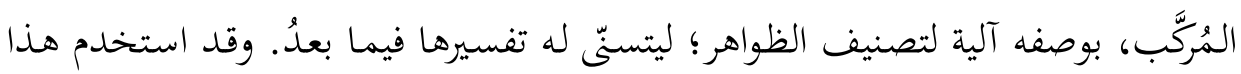

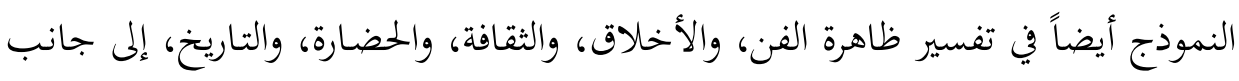

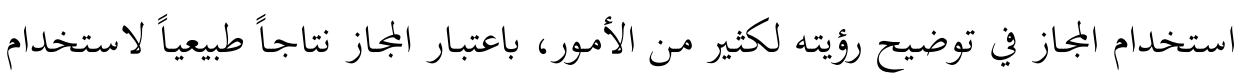




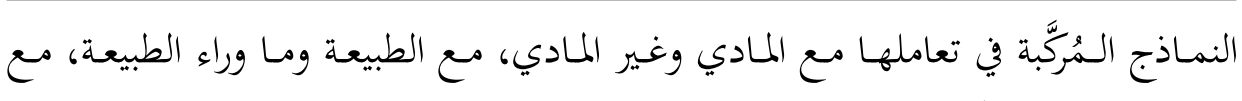
الظاهر والباطن. إنَّ الطريقة التي حاول فيها بيجوفيتش إثبات عجز النماذج الواحدية عن

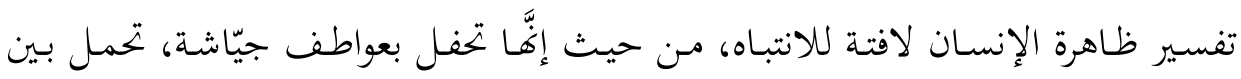

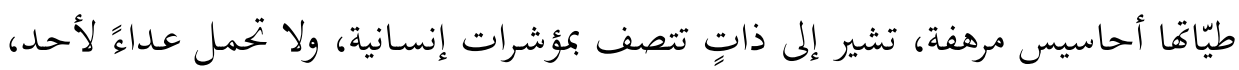
بالرغم من أنَّ البيئة التي أحاطت به كانت شديدة العداء له ولفكره.

\section{3. الرؤية التوحيدية عند علي شريعتي وعلي عزت بيجوفيتش:}

إنَّ الرؤية التوحيدية في نموذج شريعتي تقوم على الفكرة الأساسية التي مفادها أنَّ "ثمَّة

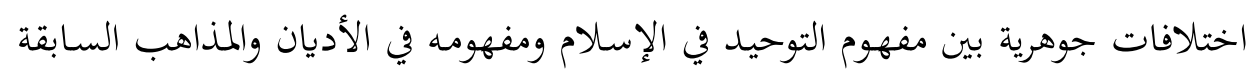

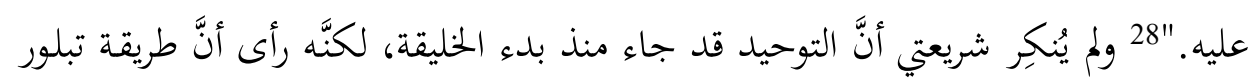

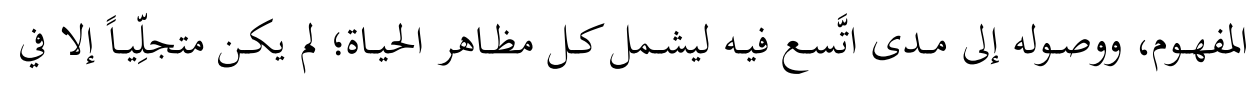
العصر الذي جاء به الإسلام.

وأشار شريعتي إلى مسألة تتعلَّق بطبيعة التوحيد في الإسلام، مفادها أنَّه "ليس أصلاً

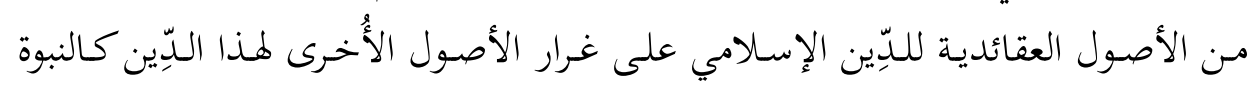

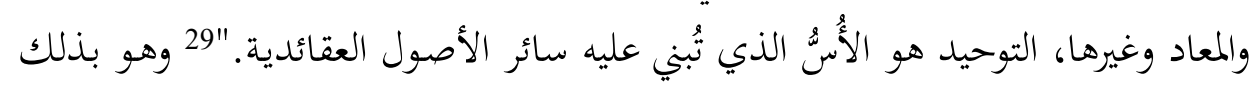

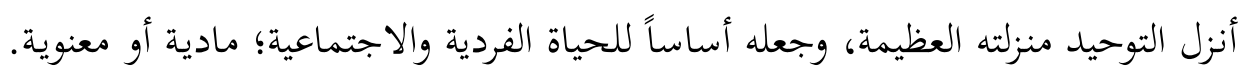

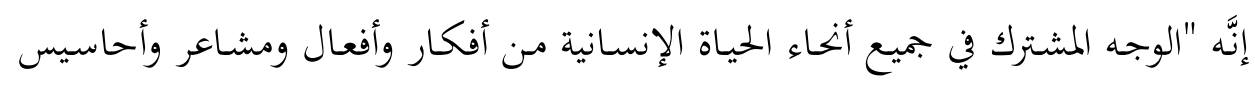
على اختلاف أشكالها وكيفياتا. "30

ومنهجية شريعتي في طرح التوحيد تختلف عن الطرح التقليدي؛ فهو يطرح رؤيته هذه

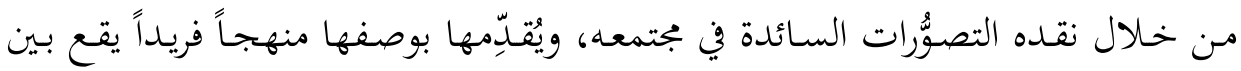

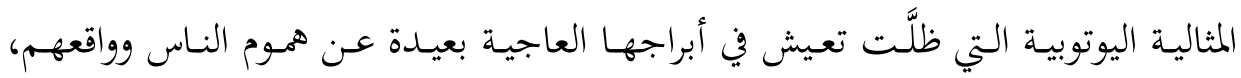

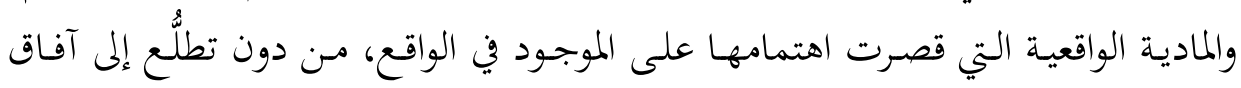

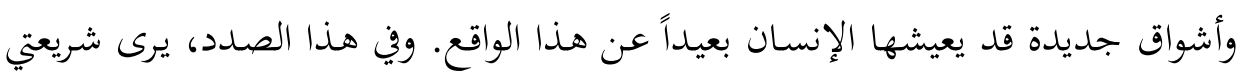

$$
\begin{aligned}
& 28 \text { شريعتي، معرفة الإسلام، مرجع سابق، ص136.142. }
\end{aligned}
$$

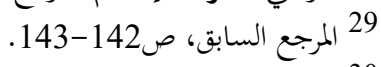

$$
\begin{aligned}
& 30 \text { المرجع السابق، صلمجع، ص144. }
\end{aligned}
$$




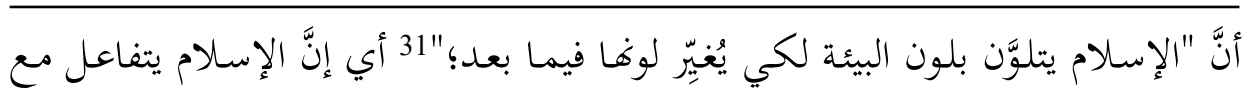

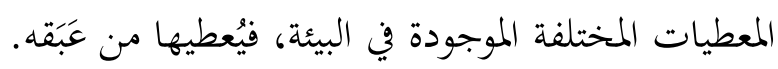

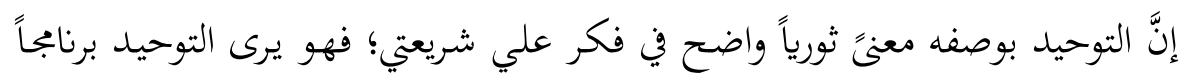

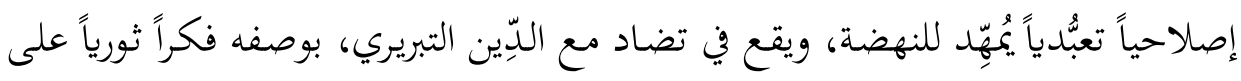

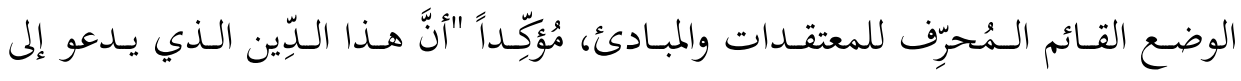

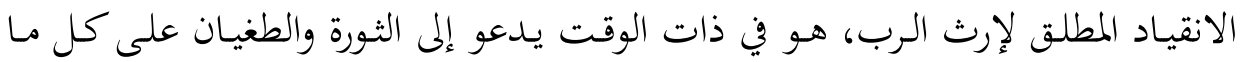

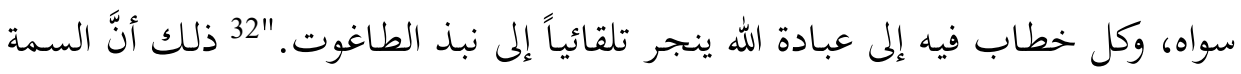

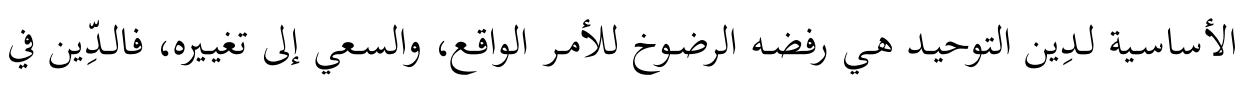

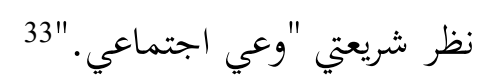

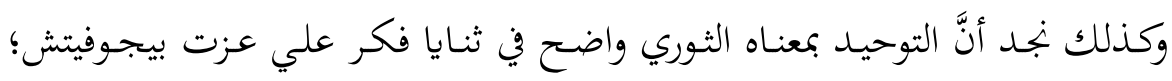

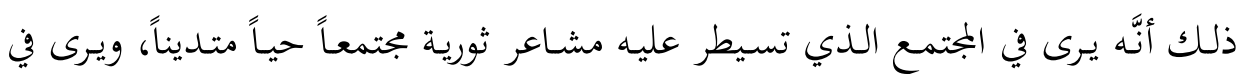

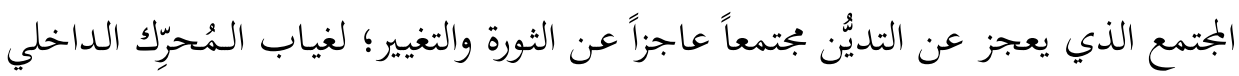

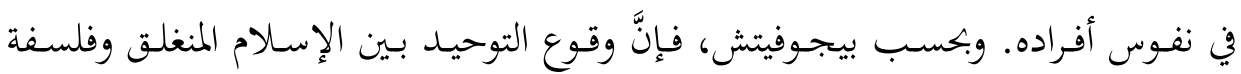

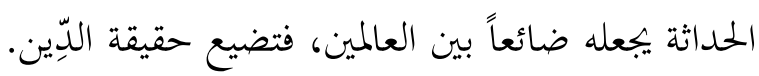

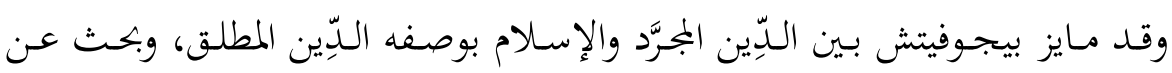

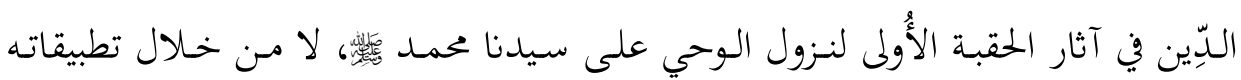

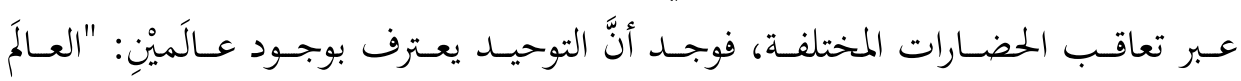

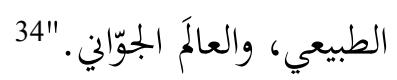

ورأى بيجوفيتش أنَّ الإسلام جامع للشرق والغرب من حيث تعرُّهه للديانة اليهودية

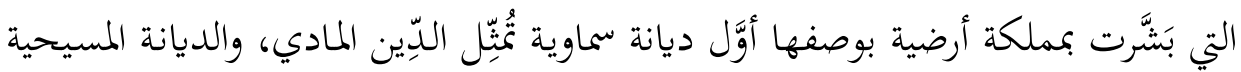

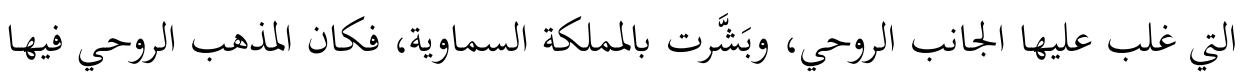
يختلف اختلافاً كلياً عمّا في الديانة اليهودية، وأصبح الجمع بينهما هو صميم فكرة الثنائية

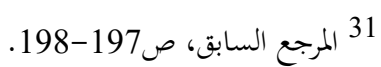

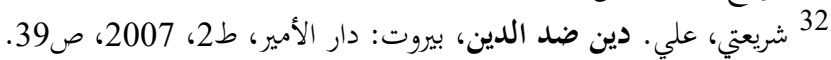

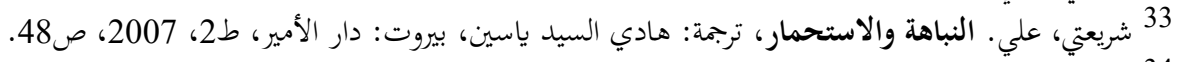

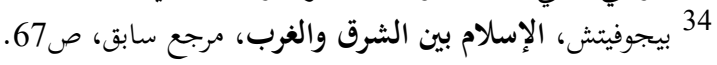




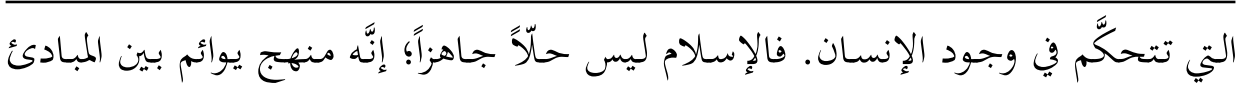

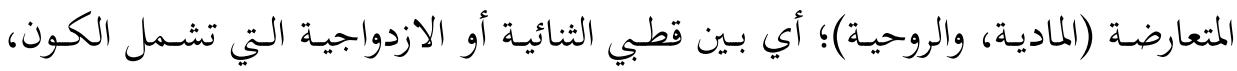
وكتابه القرآن الكريم الذي يجمع بين "واقعية" العهد القديم و "مثالية" العهد الجلديد.

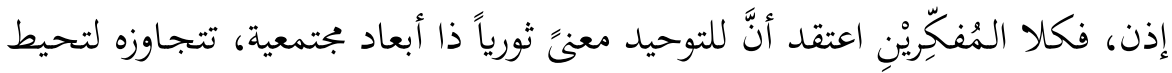

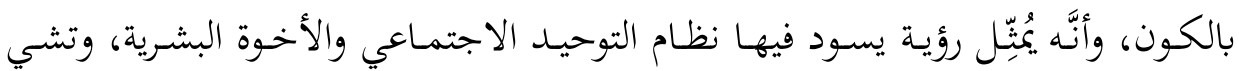

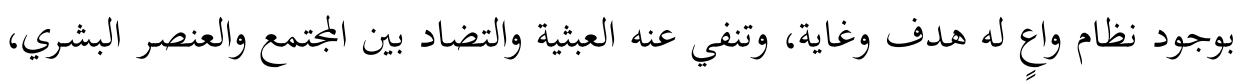

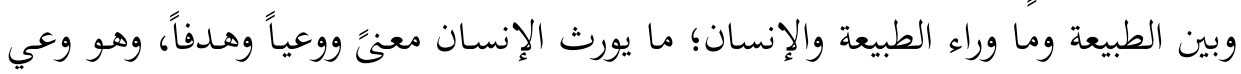
ينعكس على الأفراد حكمةً وسعياً وعمارةً للأرض وسلاماً للبشرية.

\section{ثالثاً: الإنسان في رؤية علي شريعتي وعلي عزت بيجوفيتش}

\section{1. الإنسان الخليفة عند شريعتي، والإنسان ذو الأصول الربانية عند بيجوفيتش:}

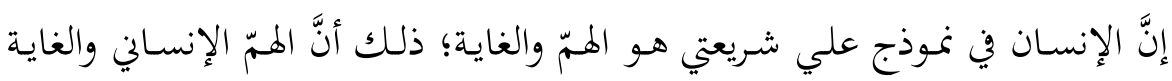

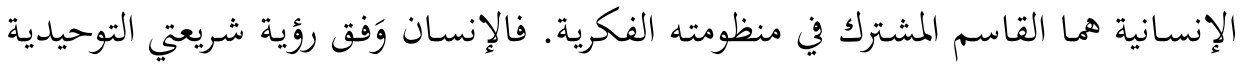

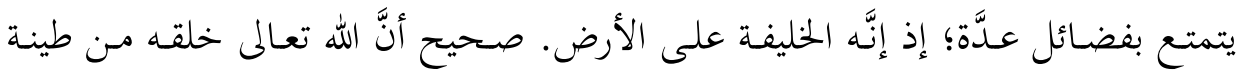

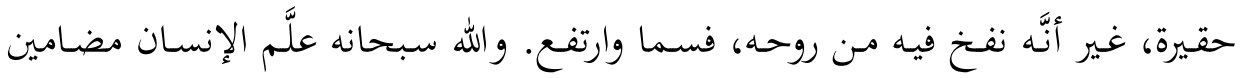

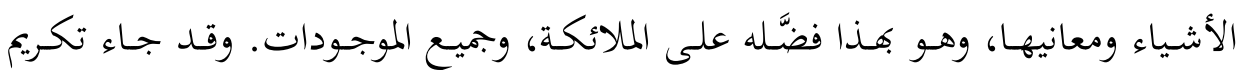

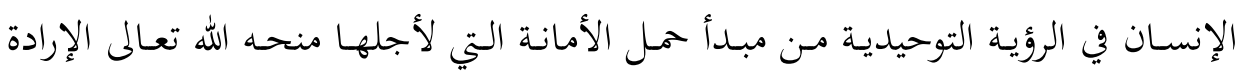
والحرية والاختيار، فانفرد بها دون غيره من المخلوقات.

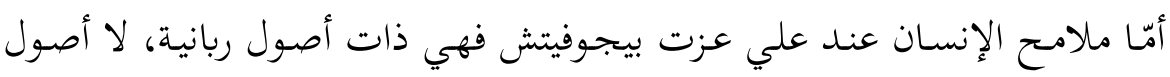

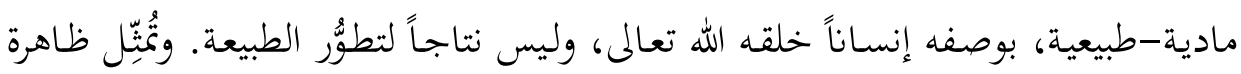

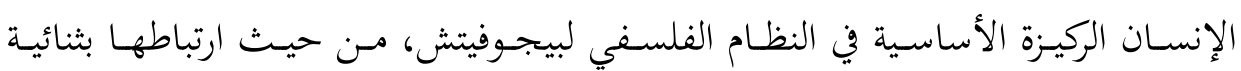

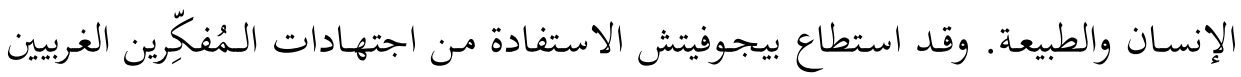

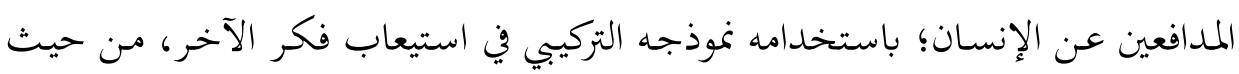
إيمان هذا الآخر بالإنسان ومركزية وجوده في الكون، وإدراكه ثنائية الطبيعة البشرية فيه.

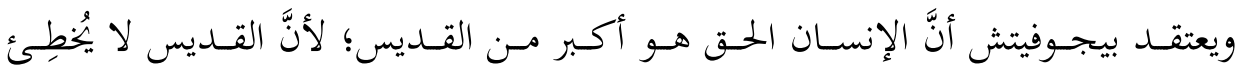




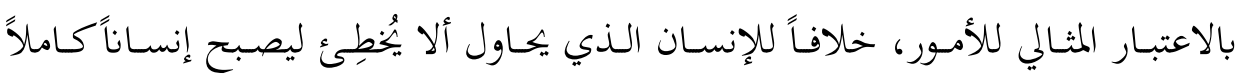

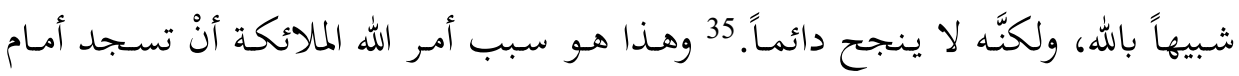

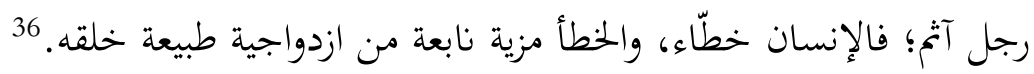

\section{2. الإنسان عند شريعتي وبيجوفيتش مقارنةً بالفلسفات المختلفة في نظرتما إلى}

الإنسان: - (الإن

بحث شريعتي عن الإنسان في التصوُرات المختلفة، بدءاً بأرسطو، ومروراً بالديانات

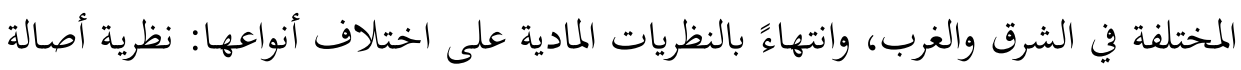

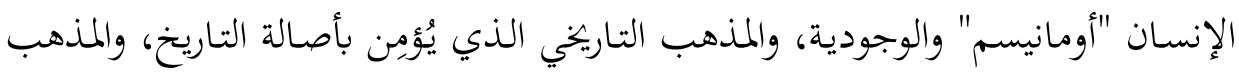

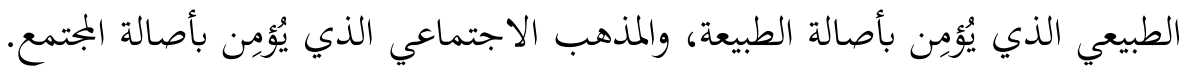

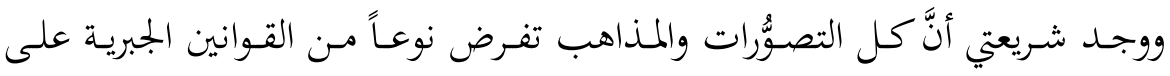

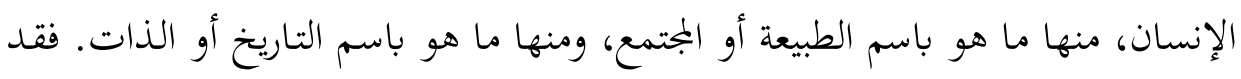

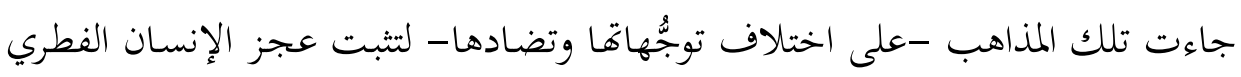

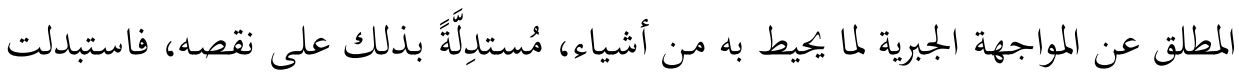

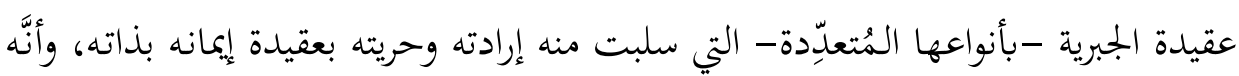

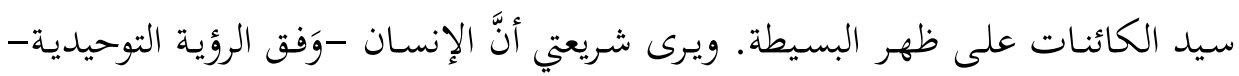

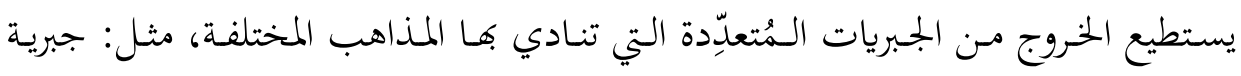

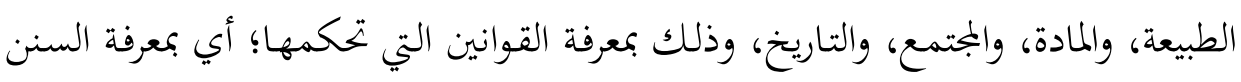

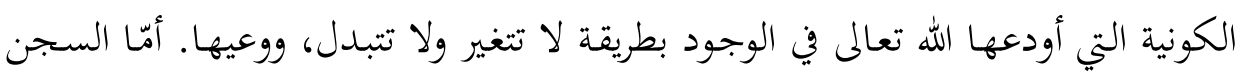

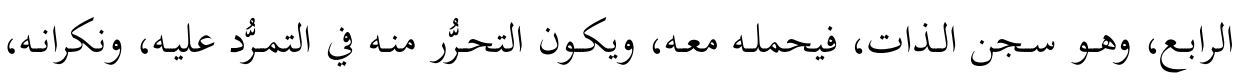
وإماتة ذاته، فيتحرَّر منه في التزام الدّيّن والعقيدة.

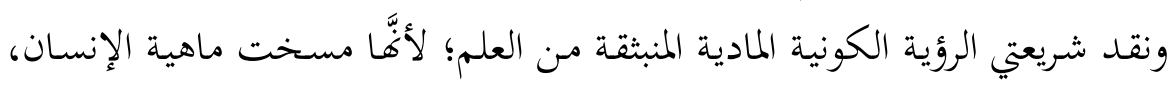

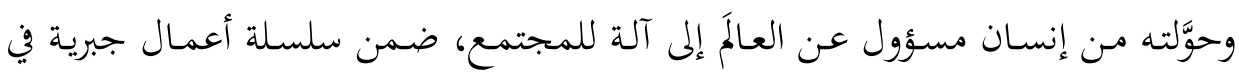

35 بيجوفيتش، علي عزت. هروي إلى الحرية، ترهمة: إسماعيل أبو البندورة، تحقيق: كمد أرناؤوط، دمشق: دار الفكر،

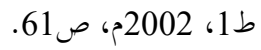

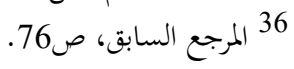


النظام الاقتصادي المادي؛ مـا جعله يسقط في رقِّ العبودية للنظام المسيطر. ونقد أيضاً

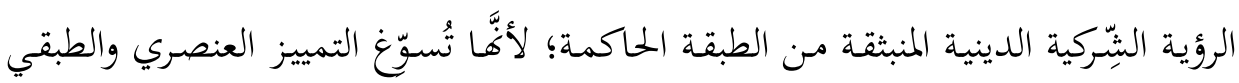

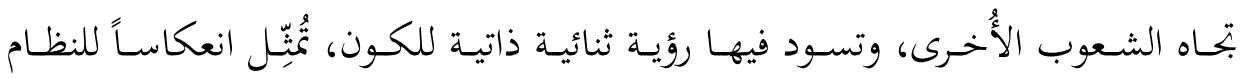

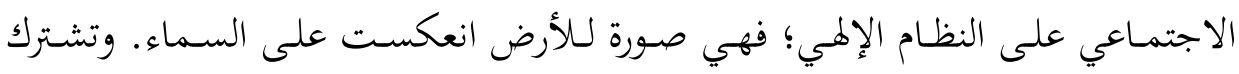

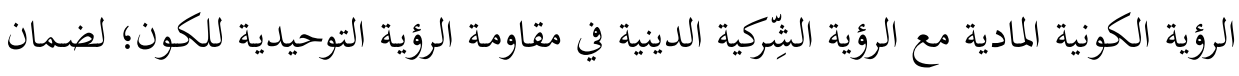

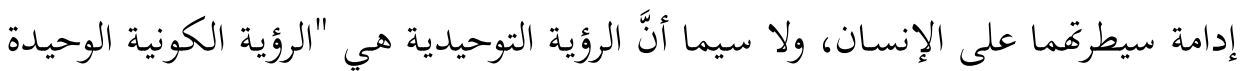

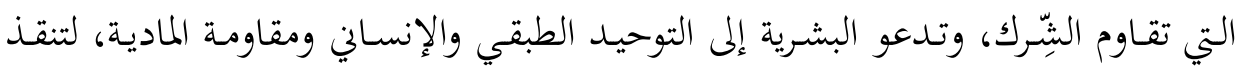
الطبيعة من الخطاط المعنى الوجودي، ولتخبر الإنسانية بعظمة رسالتها الإلهية، باعتبارها

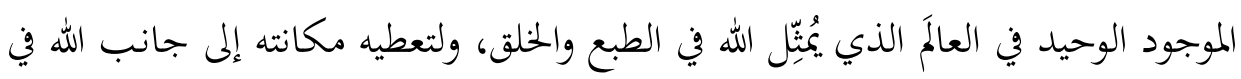

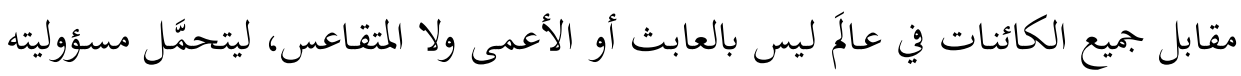

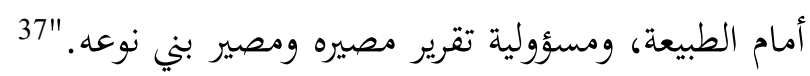

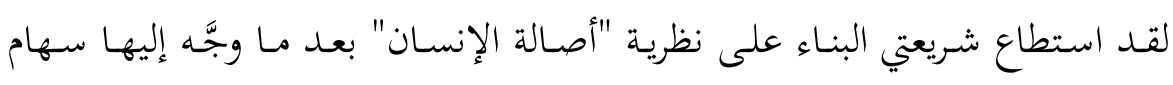

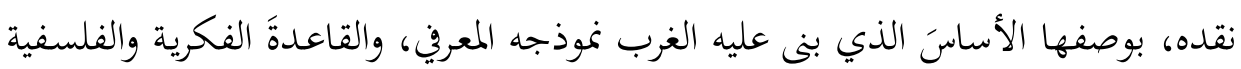

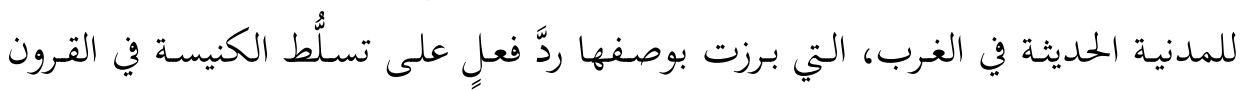

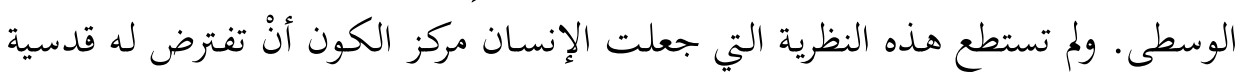

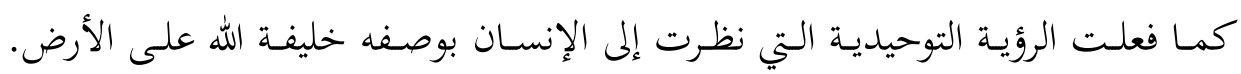

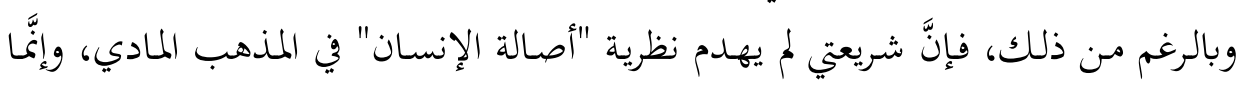

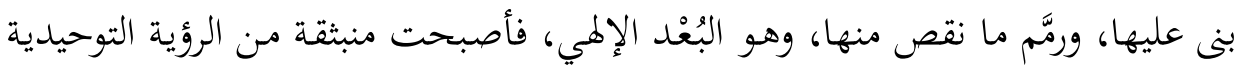

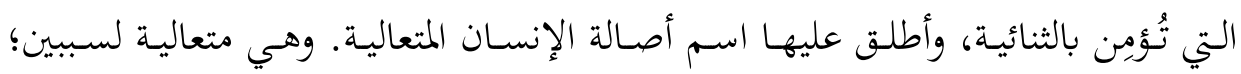

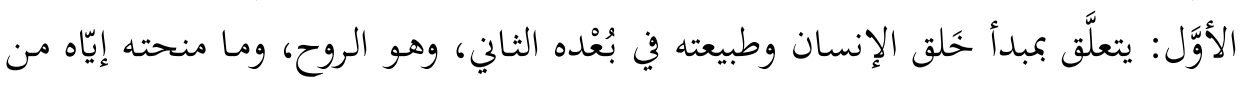

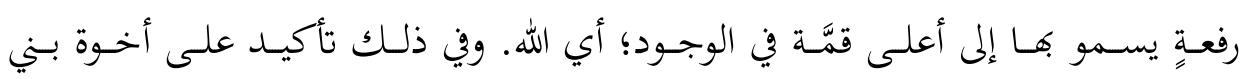

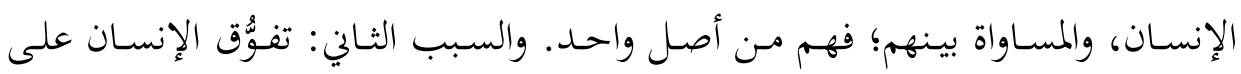

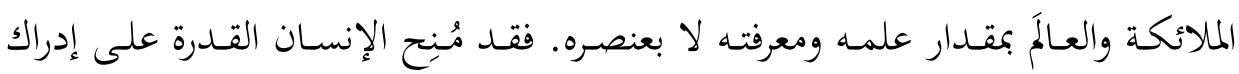

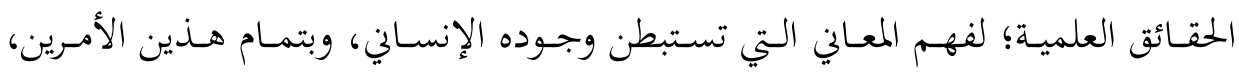




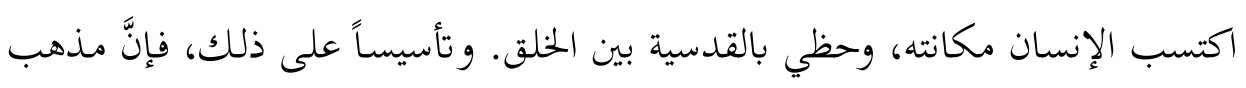

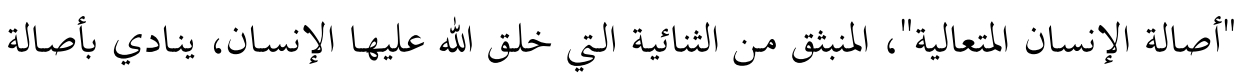

$$
\text { الإنسان، ويعترف "بقيمته وعظمة خصائصه وقدراته. "38 }
$$

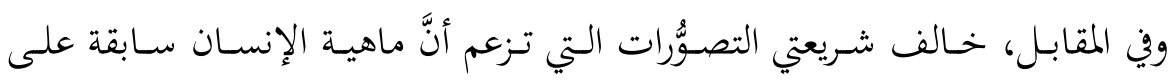

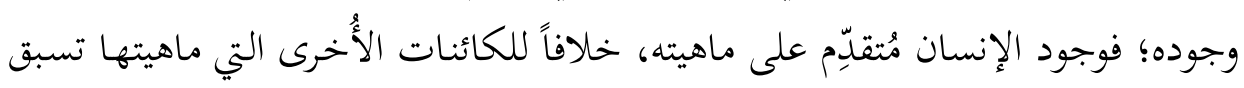

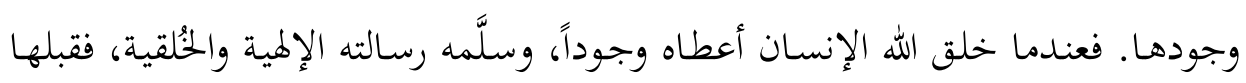

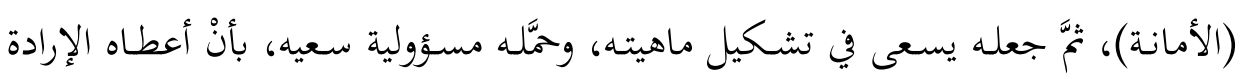

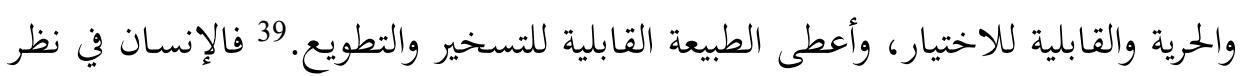
شريعتي هو "إمكانية نسبية،" "40بمنى أنَّ رسالته تكمن في تكييف وابيف المحيط حسب حسبية حاجته

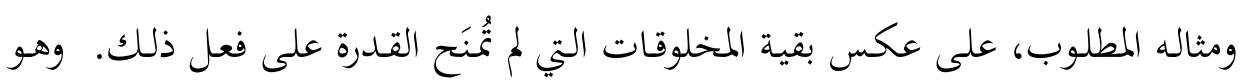

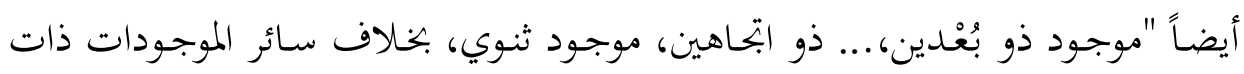

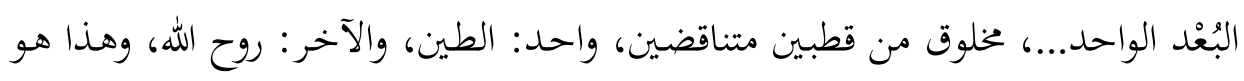

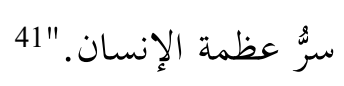

وفي إطار تفنيد الدعاوى التي تقوم عليها الفلسفات المادية، يرى شريعتي أنَّه يوجد

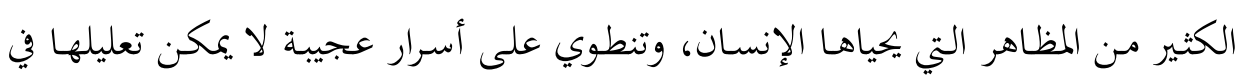

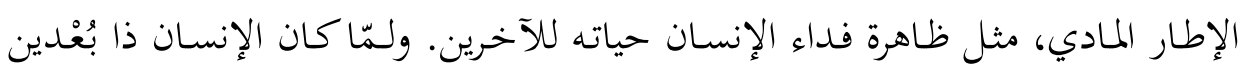

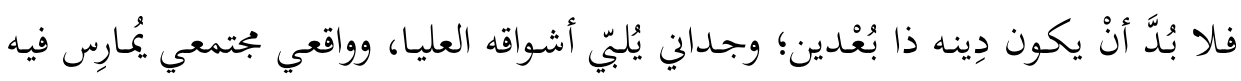

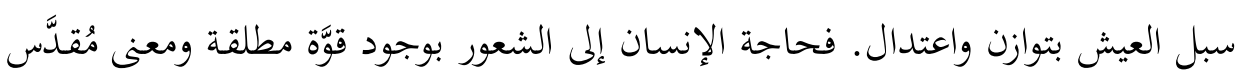

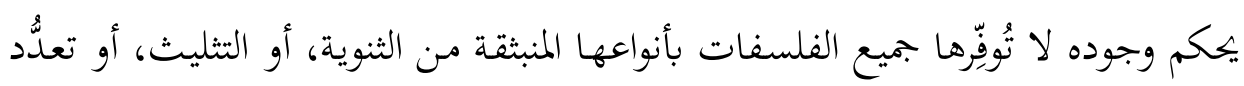
الآلمة؛ ما جعل التوحيد -في دِين الإسلام- هو المانح الوحيد لوجود الإنسان معنىً وقيمةً وهدفاً، انطلاقاً من أنه يستبطن كل مظاهر الحياة ببُعْديها: المادي، والمعنوي.

$$
\text { 38 } 38 \text { المرجع السابق، ص11. }
$$

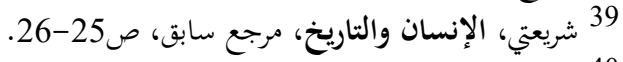

$$
\text { 40 المرجع السابق، ص64. }
$$

41 شريعتي، الإنسان والإسلام، مرجع سابق، ص18-19. 
والإنسان في التصوُّرات المغايرة للتوحيد، مثل الثنوية الزردشتية والمانوية، يخضع لقوَّة تتحدّى الله (أي الشيطان)، ولا يستطيع الخروج منها؛ إذ هو مُقيَّد بها، خلافاً للإنسان إنسان

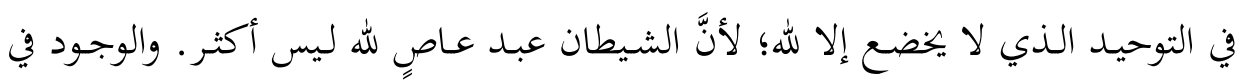

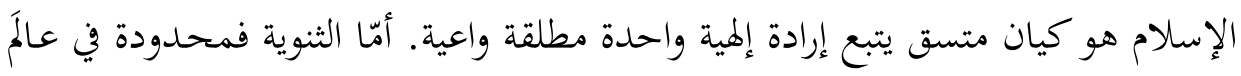

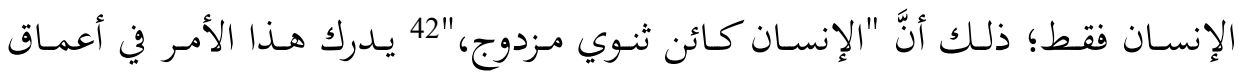

ويرى شريعتي أنَّ انتشار مظاهر العودة إلى الدِّين هو دليل ساطع على عجز الإنسان

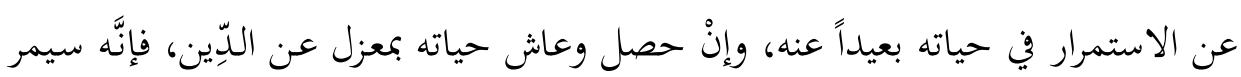

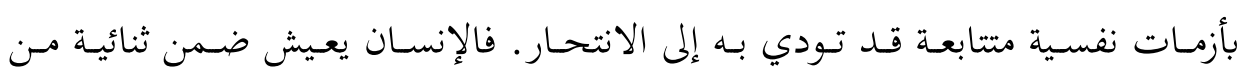
العذاب؛ عذاب مادي مُتعلِّق بحاجاته الغريزية، وعذاب فلسفي مُتنعلِّق بما وراء الطبيعة.

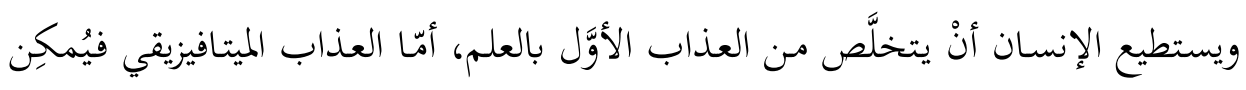
تجنبّه باللجوء إلى الله؛ أي بالإنسان انيخان.

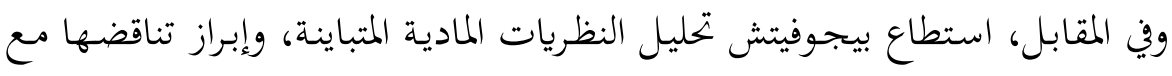

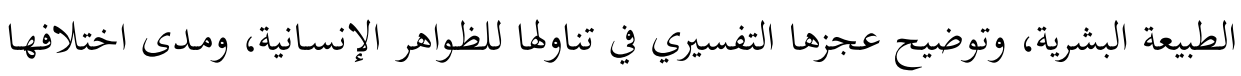

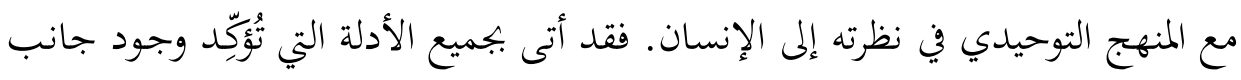
في الظاهرة الإنسانية لم تستطع المادية احتواءه وتفسير وجودهه في سياق الثنائية الجوهرية التي يُؤْن بها، والتي تنطلق من التوحيد في نظرته إلى الإنسان.

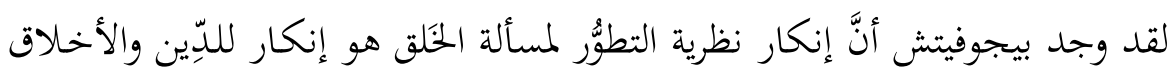

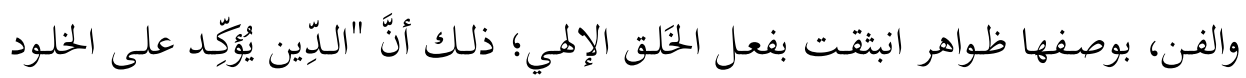

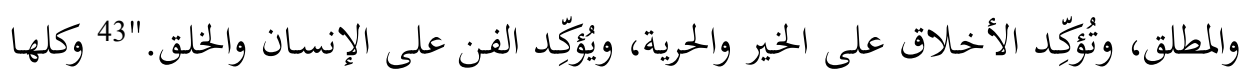

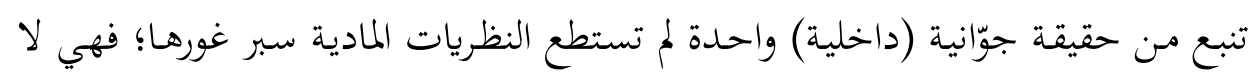

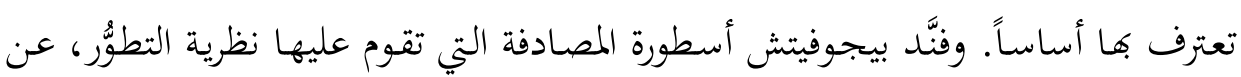

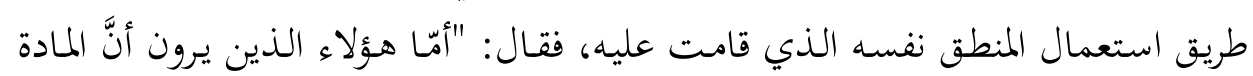

$$
\begin{aligned}
& 42 \text { شريعتي، معرفة الإسلام، مرجع سابق، ص206. } \\
& 43 \text { بيجوفيتش، الإسلام بين الشرق والغرب، مرفع، مرجع سابق، ص150. }
\end{aligned}
$$


(من خحلال المصادفة وحدها) قد أدَّت إلى ظهور عناصر متجاوزة للمادة مثل الإنسان

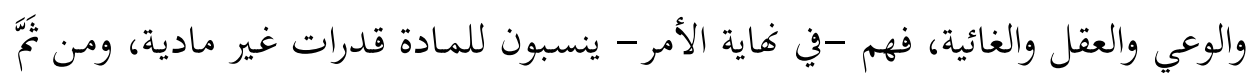

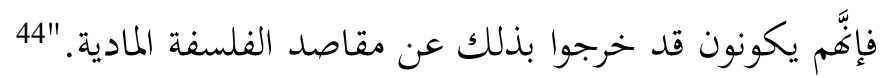

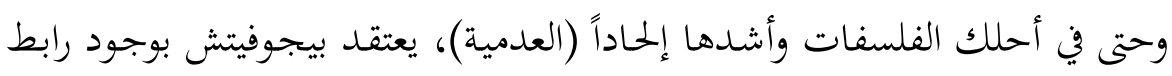
مشترك يجمع بين هذه الفلسفات والدّدين، هو بحثث الإنسان عن الإله. فالعدمية ليست

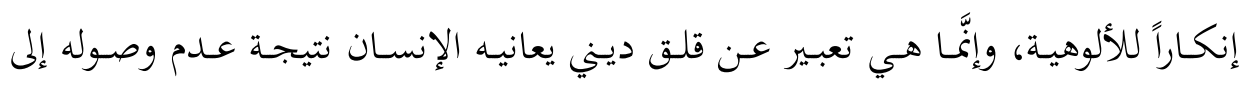

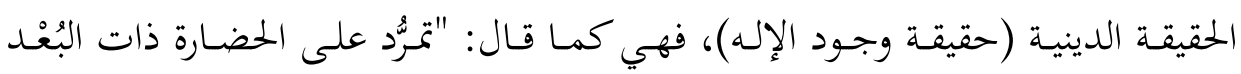
الواحد"45 التي أخرجت الإنسان من حسابها، فلم يعد له مكان فيها.

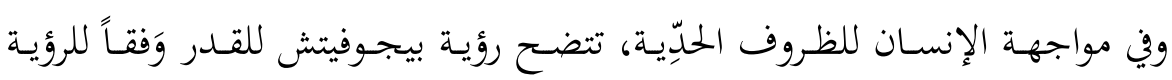

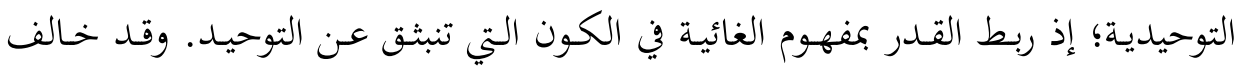

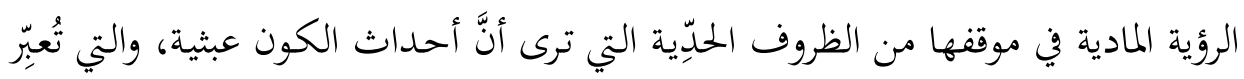

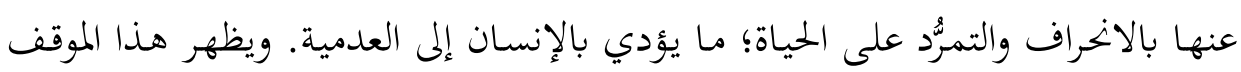

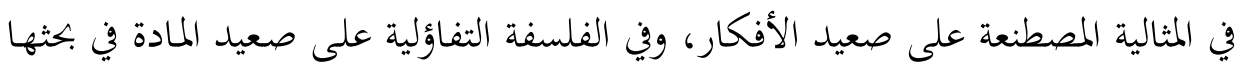
عن الأفضل من كل ما هو ممكن، من منطلق أنَّ الأشياء تتصارع في ما بينها حتى تصل إلى أفضل صورة لها.

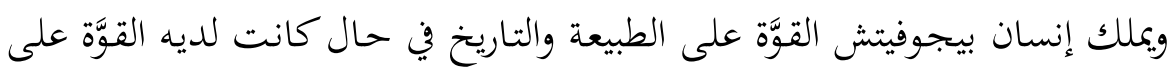

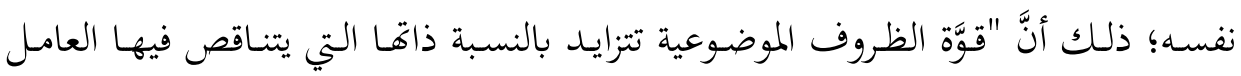
الفردي... فكلما أصبح هذا العامل الفردي خاملاً غير فعال نقص قدره من الإنسانية،

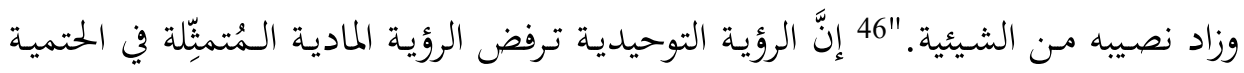

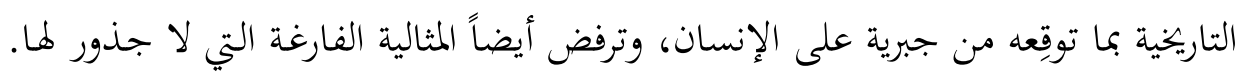

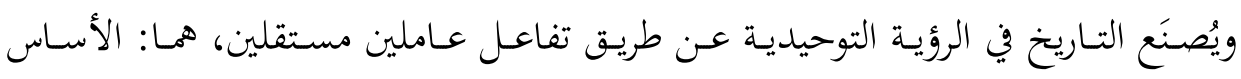

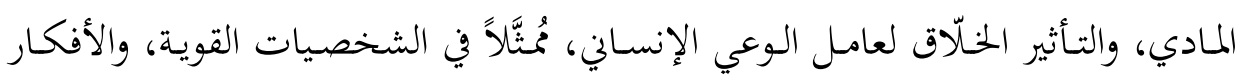

$$
\begin{aligned}
& 44 \text { المرجع السابق، ص16. } \\
& 45 \text { المرجع السابق، صلرجع المان، ص138. } \\
& 46 \text { المرجع السابق، ص28 المان، ص29. }
\end{aligned}
$$


الكـبرى، والمُّثل العليا. وكلما عظمت القوَّة الروحية لصانع الأحسداث في التـاريخ عظم استقلاله عن القوانين الخارجية. فالإسلام هو البحث الدائم عبر التاريخ عن حالة التوازن بين الجوّاني والبرّاني بهدف تنظيم الكون. وتقابل الثنوية الإنسانية عند شريعتي الثنائية عند بيجوفيتش، التي تُمُبّل النظرة الأولىلى إلى الوجـود، وهـي ثنائيـة الوجـود الإنسـاني؛ ثنائيـة الطبيعي المـادي مـن جهـة، والإنسـاني

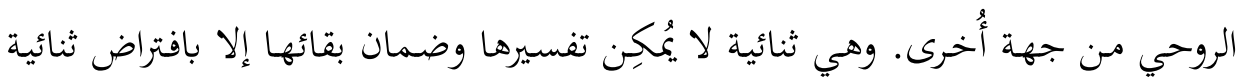

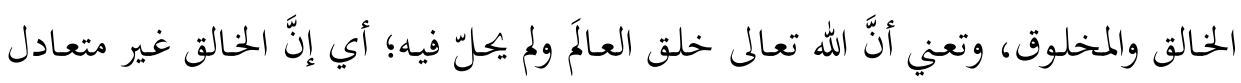

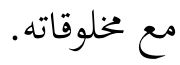

وقد أشار بيجوفيتش إلى وجود عناصر دينية تستوعب مضامين التوحيد للإنسان،

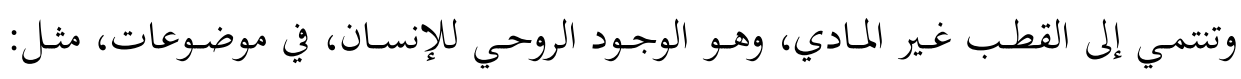

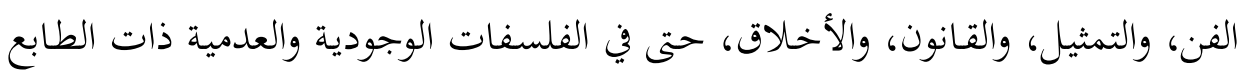
الإلحادي، وذلك بالمقارنة بين الإنسان البدائي وارتباط وجوده بظهور المخظورات وأفكار

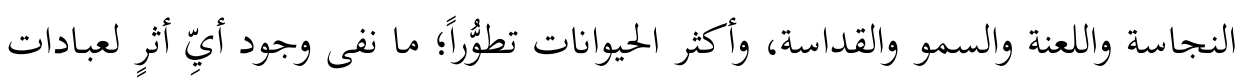

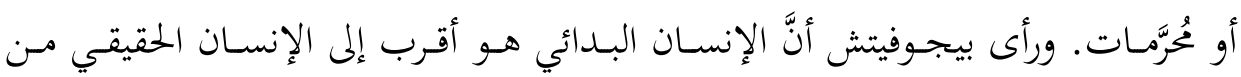

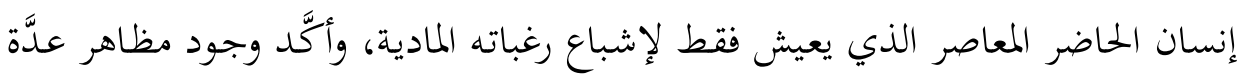

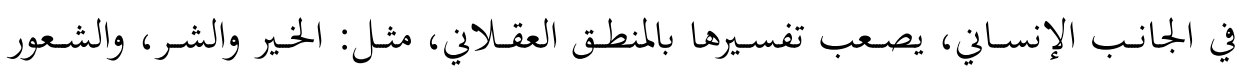

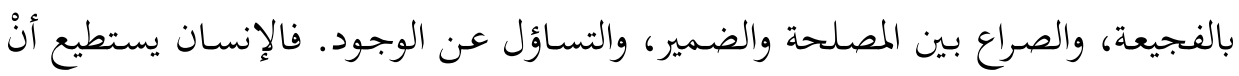
يتمرَّد؛ ما يعني أنَّه حرُّ مختار وصاحب إرادة، وبعضُ مَن يمتلكون المعاني الإنسانية يُمُكِنهم

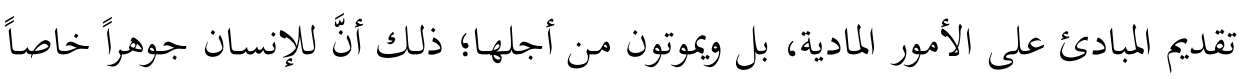
به، ومع أنَّه حيوان ببُعده المادي، فقد مُنح شخصية ذاتية. 47 فهو أكثر من جمرَّد كمية أو أو

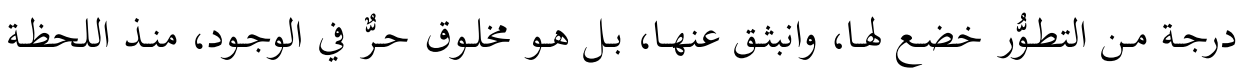

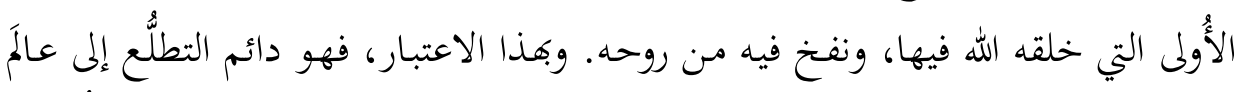

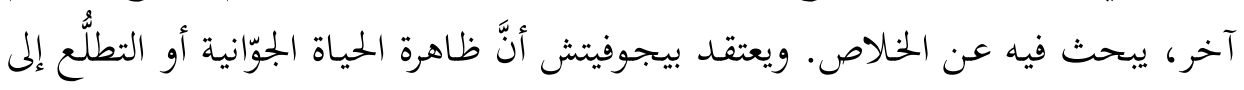

$$
\text { 47 - المرجع السابق، ص66-82. }
$$




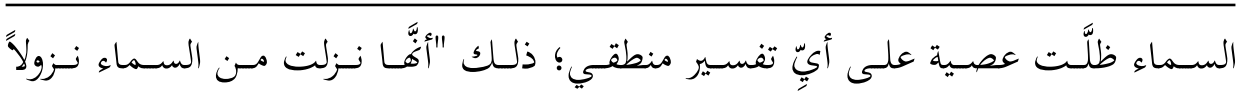

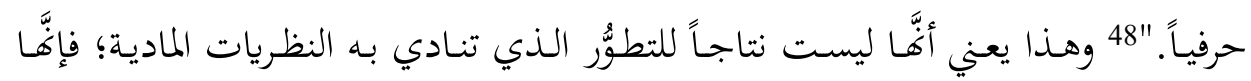
تقف متعالية عليه، ومفارقة له.

\section{3. معالم البناء الإنساين عند شريعتي وبيجوفيتش من حيث الحرية والإرادة:}

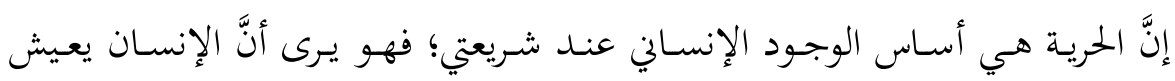

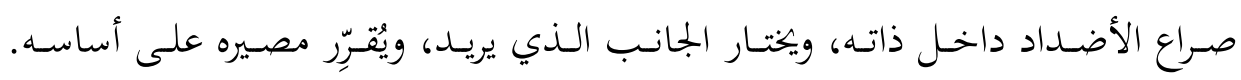

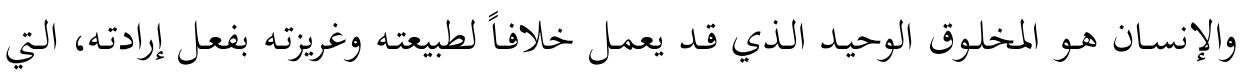

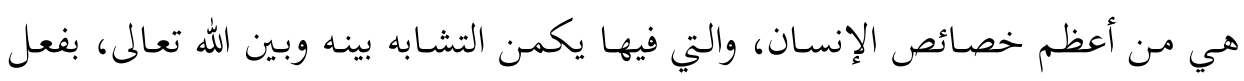

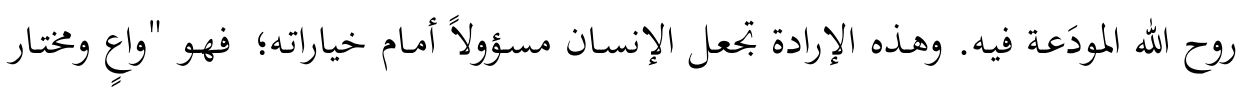

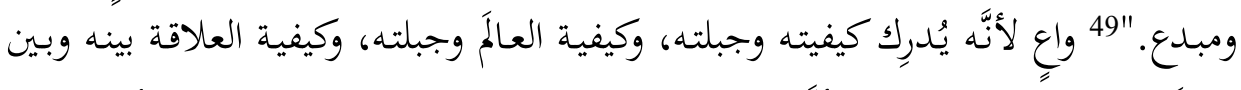

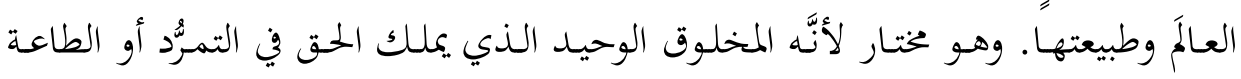

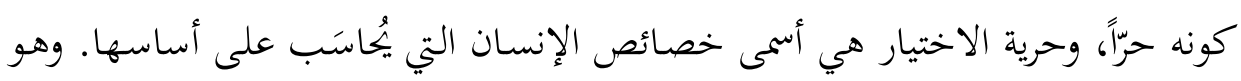

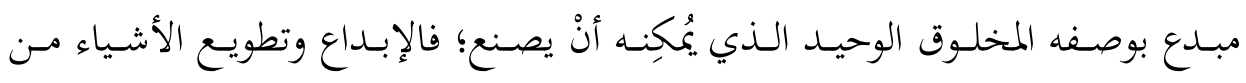
خصائص فطرته.

غير أنَّه توجد أربعة سجون تقفت حائلاًا أمام حرية الإنسان وإرادته في الوصول إلى

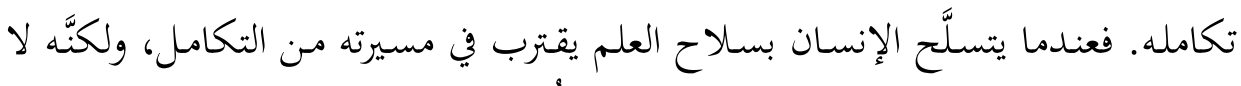

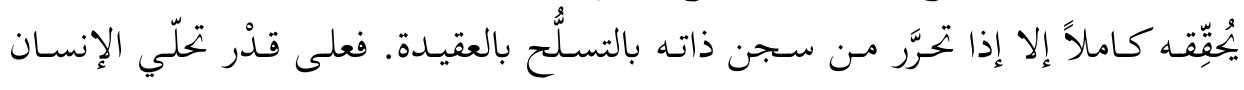

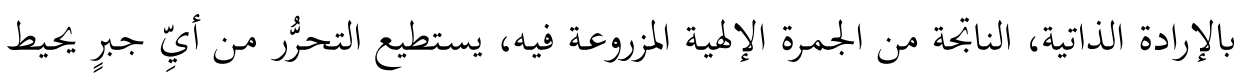

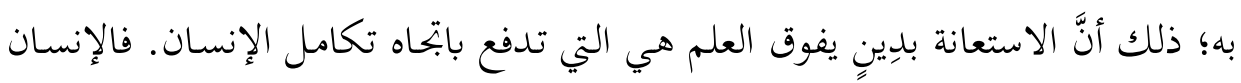

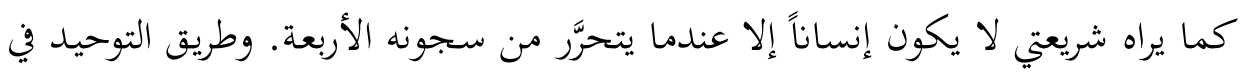

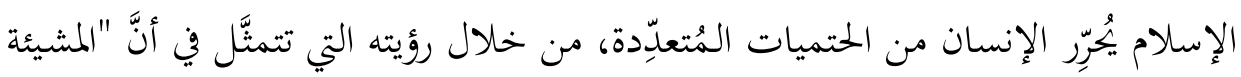

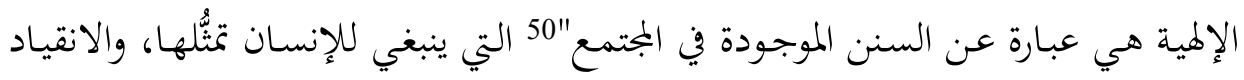

$$
\begin{aligned}
& \text { 48 المرجع السابق، ص78. }
\end{aligned}
$$

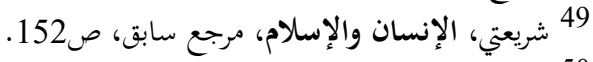

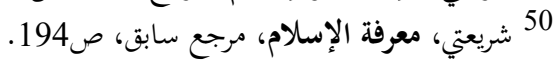


لها، إلا أنَّ الإنسان يمتلك حرية الاختيار في النكوص عنها، ويُعَدُُّ ظالماً لنفسه في حسال فعل ذلك.

والإنسـان غير البشر؛ فالبشر كينونـة شأفم في ذلك شـأن المخلوقات الأُخـرى في

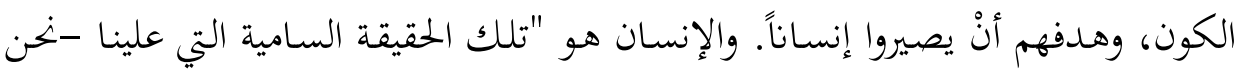
البشر - أنْ نسعى للوصول إليها، نسعى لنُجسِّدها؛ فهو عبارة عن المميزات السامية التي

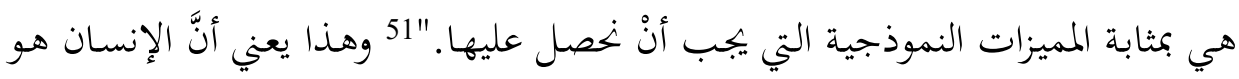

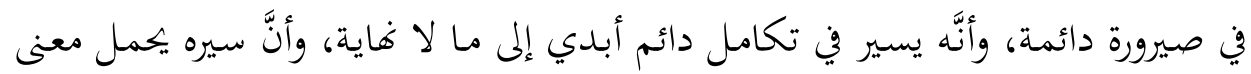
الحركة المستمرة. وبالمثل، يـرى بيجـوفيتش أنَّ الحريـة الإنسـانية هي محسور أساسي مـن محساور النظرة

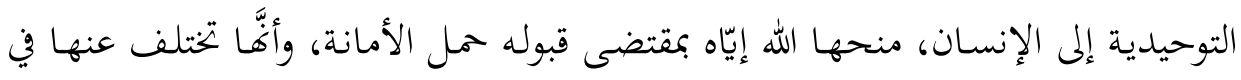
النظريات المادية التي يعيش فيها الإنسان جبر الطبيعة، والتاريخ، والمجتمع، والذات. ويرى لإن

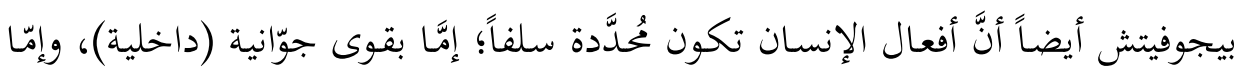

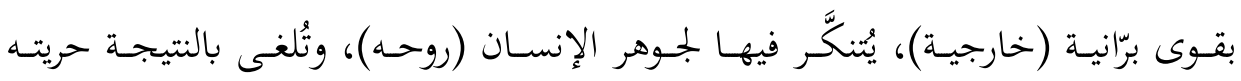

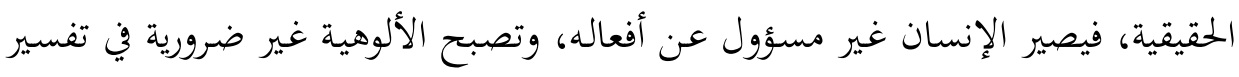
الكون وفهمه.

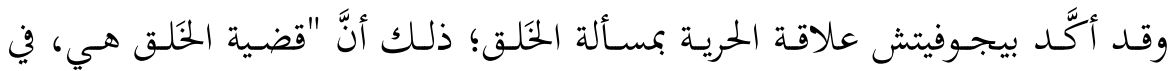

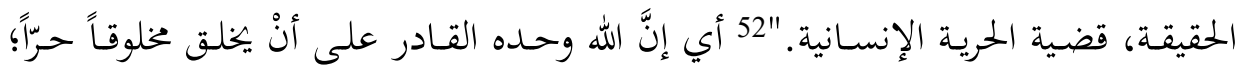

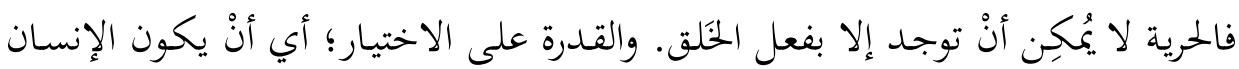

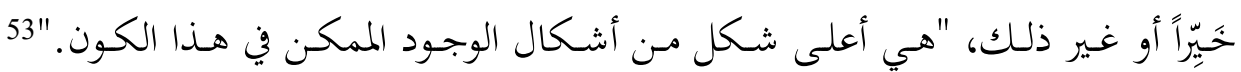

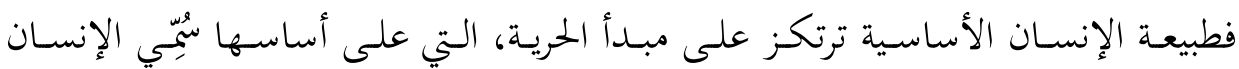

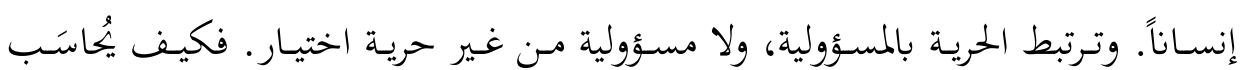
الإنسان من غير منحه قدرة على الاختيار؟!

$$
\begin{aligned}
& 51 \text { شريعتي، الإنسان والإسلام، مرجع سابق، ص151. }
\end{aligned}
$$

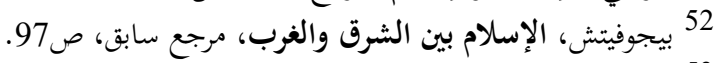

$$
\begin{aligned}
& 53 \text { المرجع السابق، صوفيتش، الإنام بين الث9. }
\end{aligned}
$$


4. معالم البناء الإنساني عند شريعتي وبيجوفيتش من حيث الأخلاق، والمساواة،

والثقافة:

يـرى شـريعتي أنَّ مـن آثار التوحيد "توحيـد العالَّ، ومـن لـوازم توحيـد العـالمَ توحيد

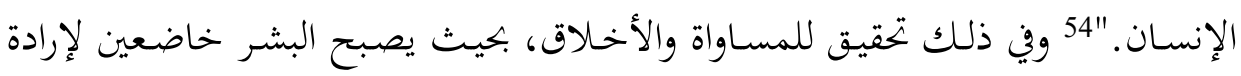

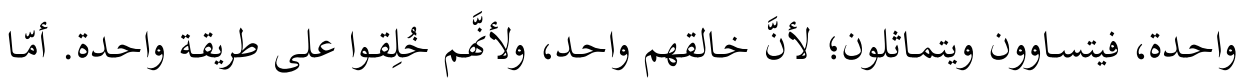

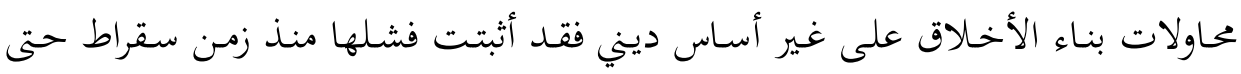

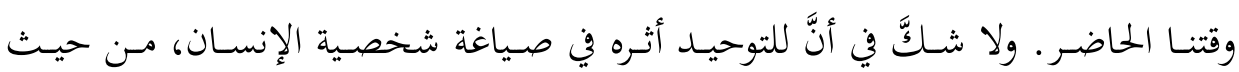

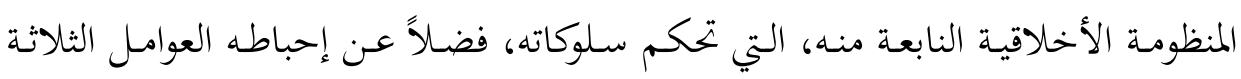

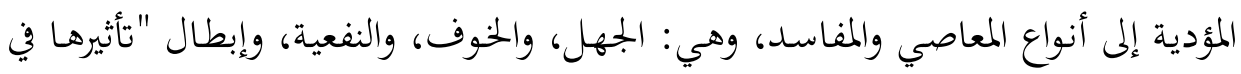

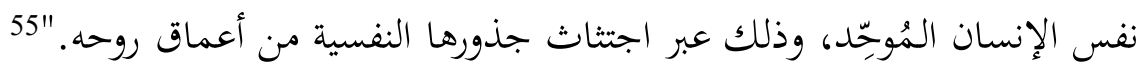

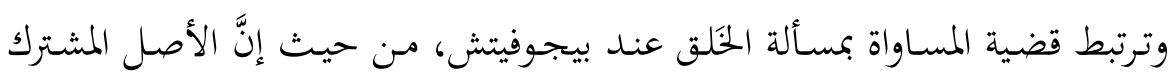
لجميع البشر هو حجر الزاوية في الأديان المنزلة، الذي يفضي عندي إلى المساواة المطلقة بينهم.

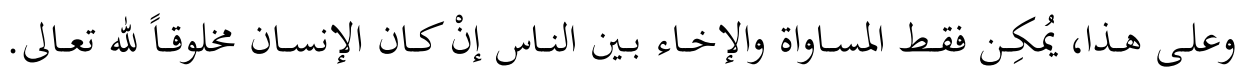
"فالمساواة الإنسانية خصوصية أخلاقية، وليست حقيقة فئة طبيعية، أو مادية، أو عقلية."

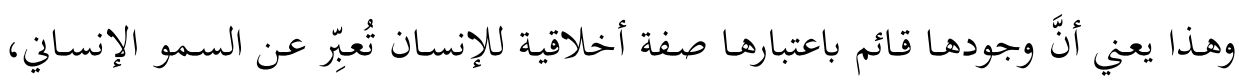

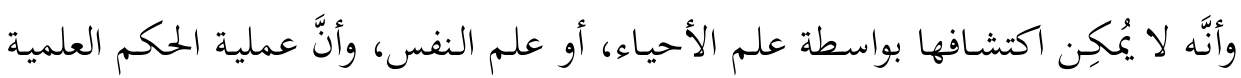
المادية لا تنطوي على فكرة المساواة أبداً.

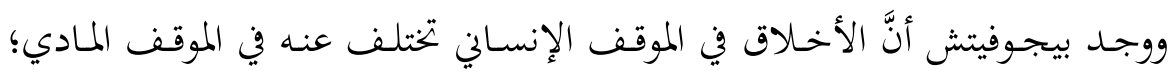

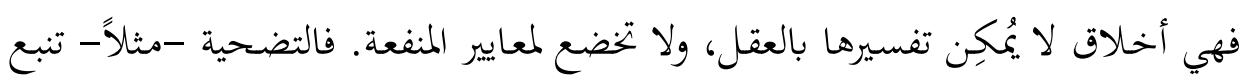

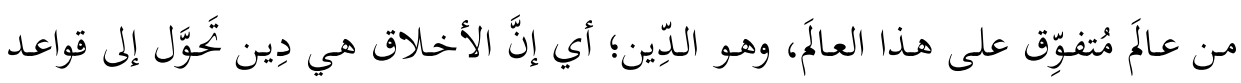

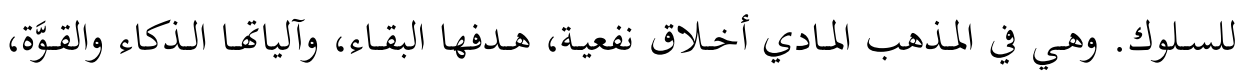

$$
\begin{aligned}
& 54 \text { شريعتي، دين ضد الدين، مرجع سابق، ص34. }
\end{aligned}
$$

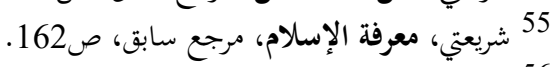

$$
\begin{aligned}
& 56 \text { بيجوفيتش، الإسلام بين الشرق والغرب، مرفي، مرجع سابق، ص100. }
\end{aligned}
$$


وهي تتبع المصلحة، وتنطلق من التسوية بين الإنسان والمادة، ويحكمها سيدان، هما: اللذة، والألم.

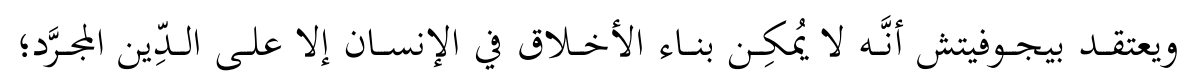

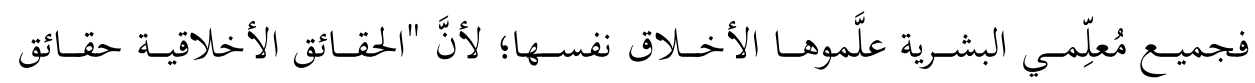

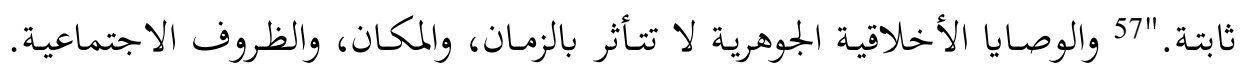

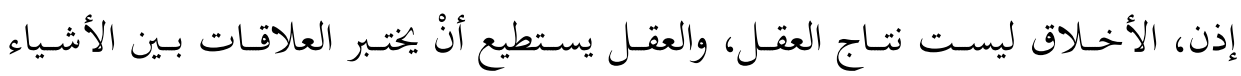

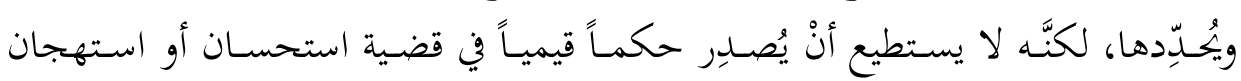

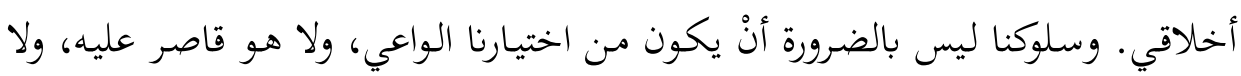

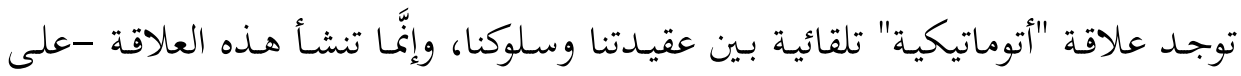

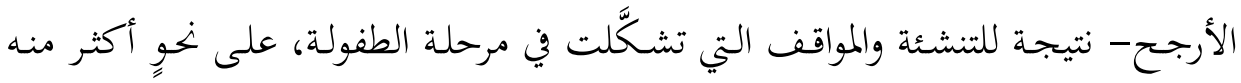

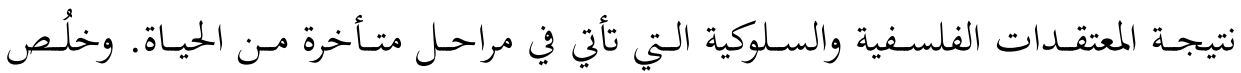

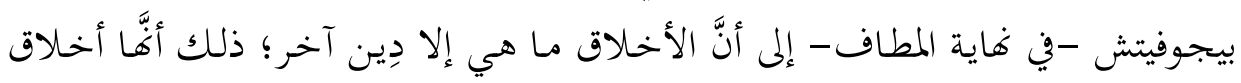
الفطرة التي أودعها الله داخل كل إنسان.

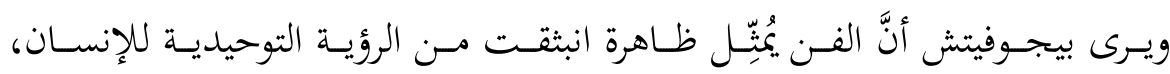

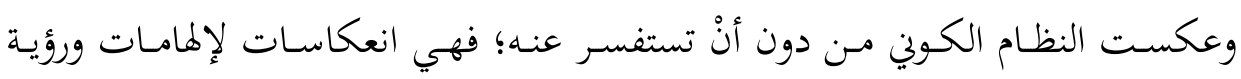

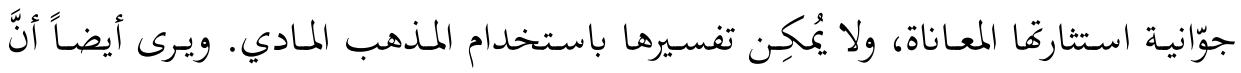

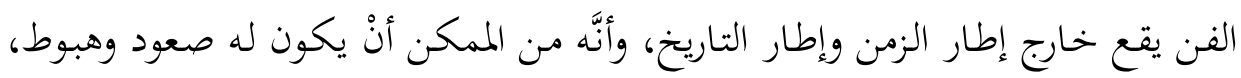

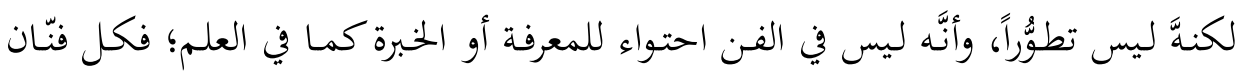

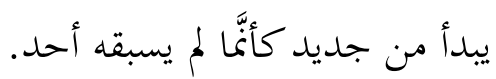

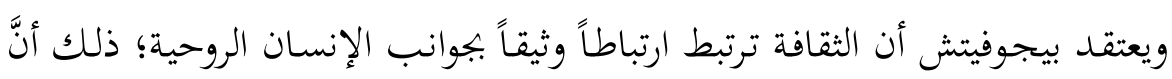

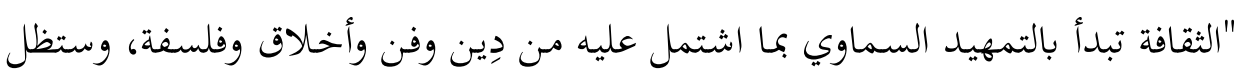

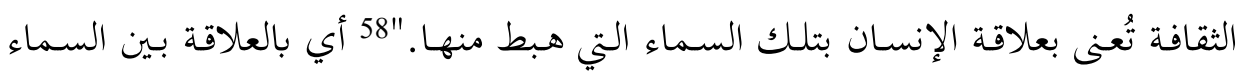

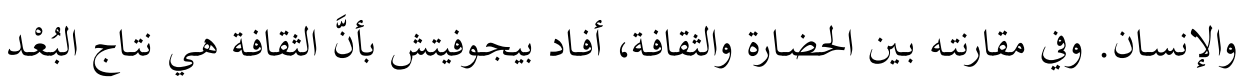

$$
58 \text { المرجع السابق، ص107. } 57 \text { المابق. }
$$




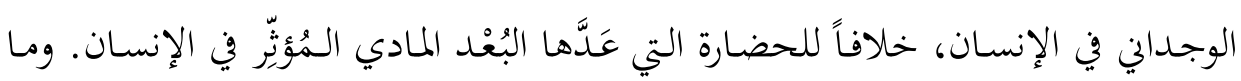

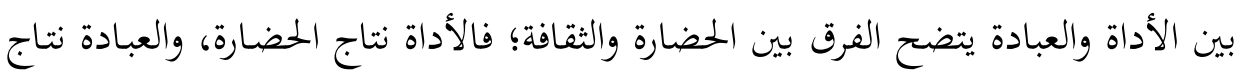

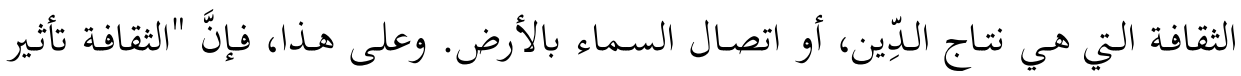

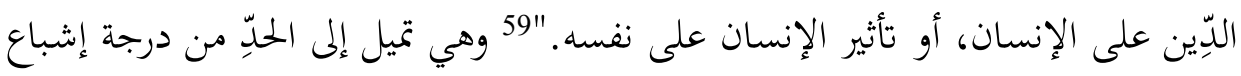

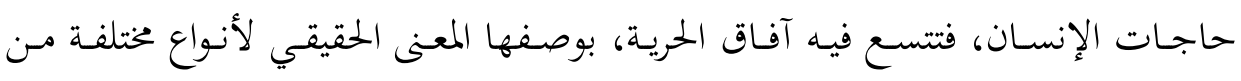

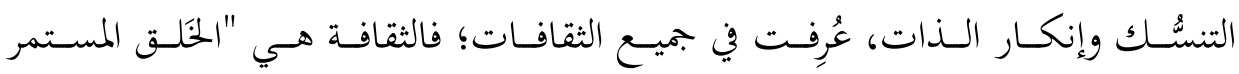

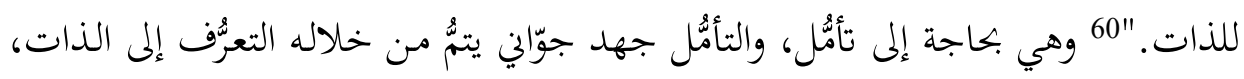

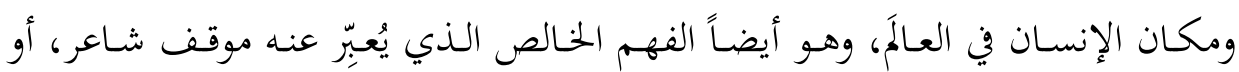
فنّان، أو ناسك.

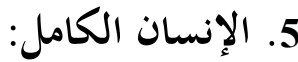

يـرى شـريعتي أنَّ الكمـال البشـري وإنسـانية الإنسـان لا يتحققَّــان إلا بتحقيـق مبــأ

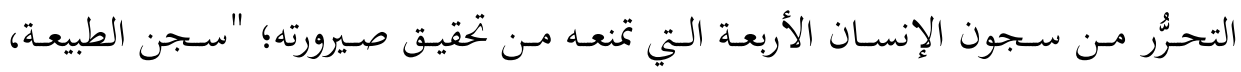

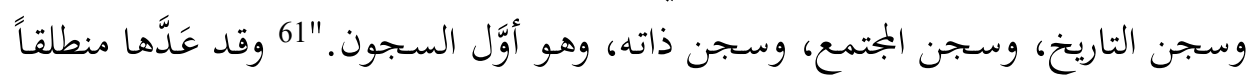

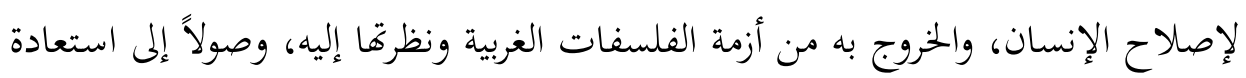

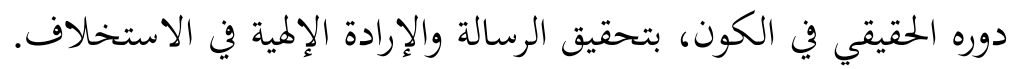

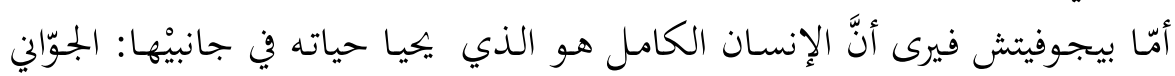

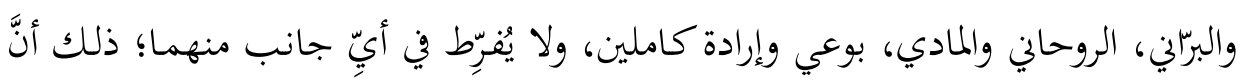

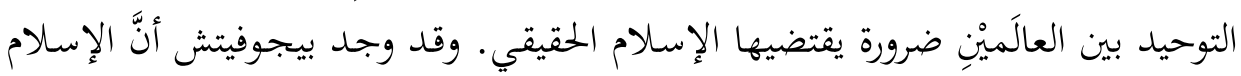

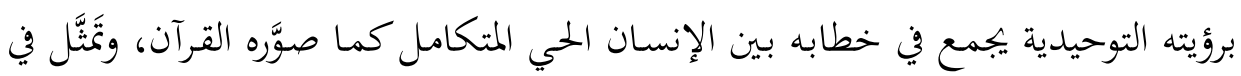

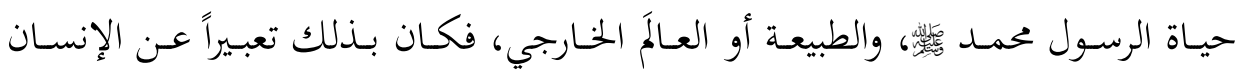

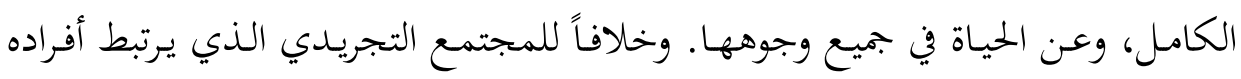

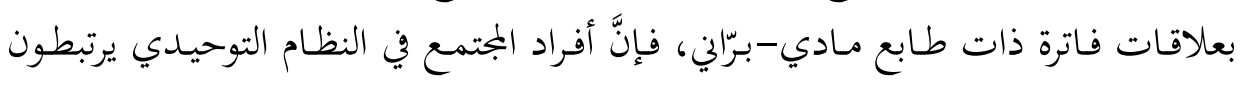
بعلاقات تتسم بطابع روحاني -جوّاني، وتقوم على التآلف في ما بينهم.

$$
\begin{aligned}
& 59 \text { المرجع السابق، ص107. } \\
& 60 \text { المرجع السابق، ص108. } \\
& 61 \text { شريعتي، الإنسان والتاريخ، مرجع سابق، ص90. }
\end{aligned}
$$


وخلاصة القول هي أنَّ ملامح الإنسان المنبثقة من الرؤية التوحيدية لكل من شريعتي

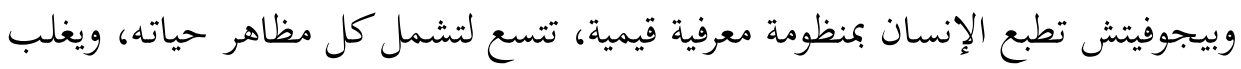

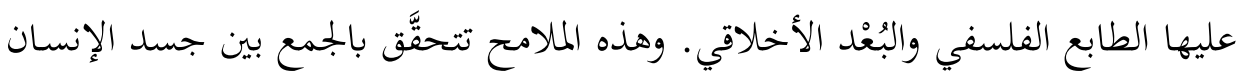

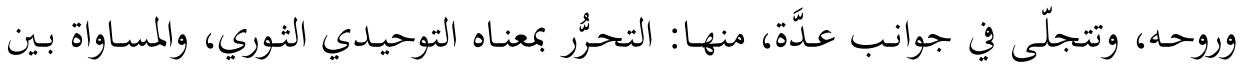

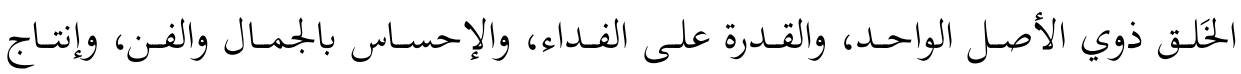
الثقافة، والتحلّي بالأخلاق ذات المصدر الديني. والإنسان -بحسب شريعتي- يُمثِّل إمكانية نسبية؛ فهو في حركة وصيرورة مستمرة،

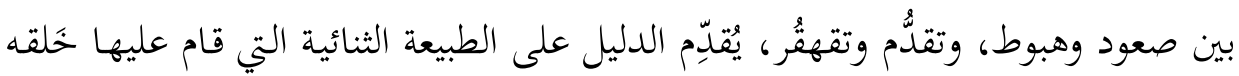

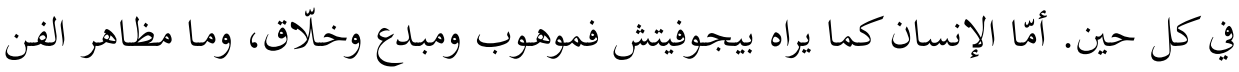
والجمال والثقافة إلا دليل يُعتدِّمه الإنسان دائماً على الطبيعة الثنائية التي خلقهـ الله عليهاه

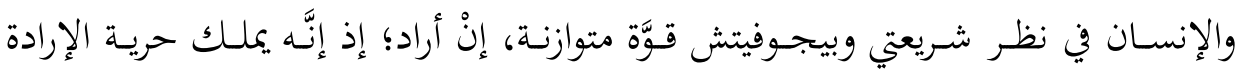
والاختيار، وهذا التوازن جاء من الطبيعة التي خلقه الله عليها لتحقيق الغاية من وجودهده.

خاتمة:

لقد فض الغرب بعدما استبدل روحاً دينية اجتماعية (البروتستانت) بالقيم الدينية

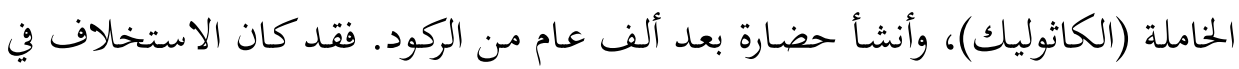

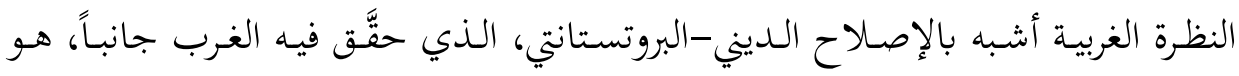

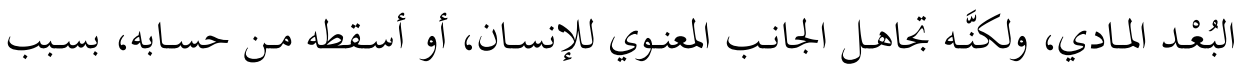

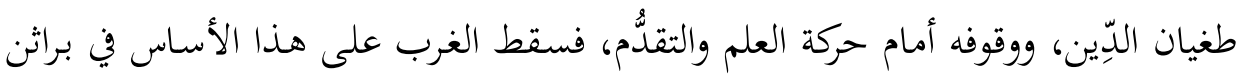

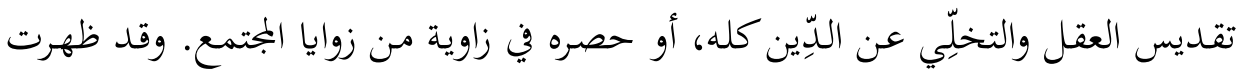

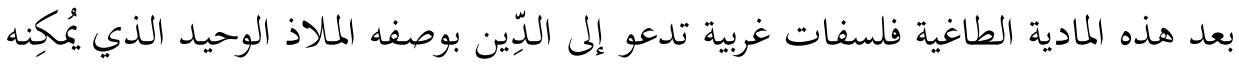

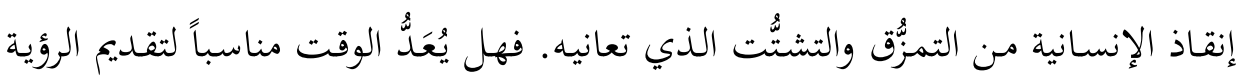

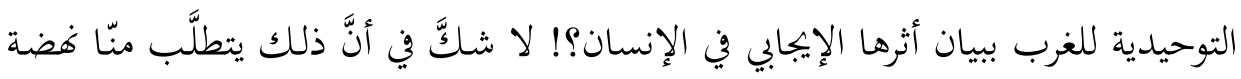
شاملة في مختلف الميادين، لإيصال رسالتنا إلى الإنسانية بالطريقة التي تليق بها. 


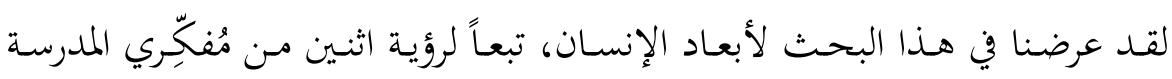

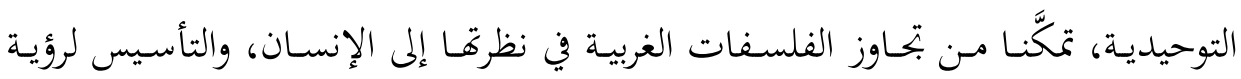

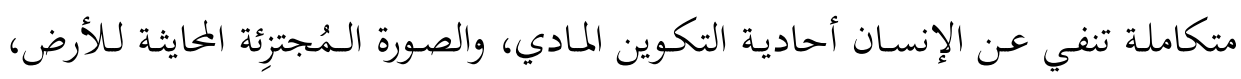
التي تنفي عنه كل ما هو متجاوز ومتعالٍ.

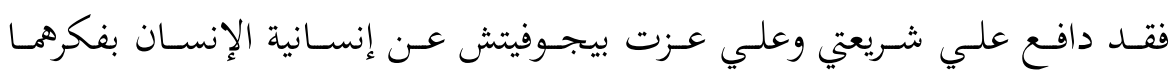

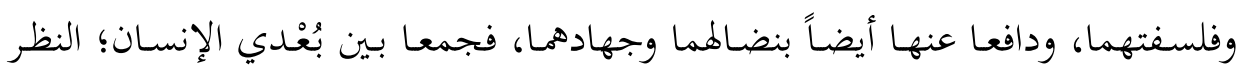

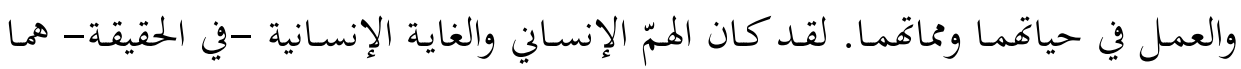

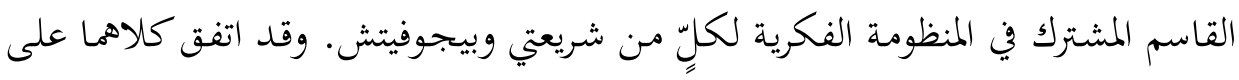

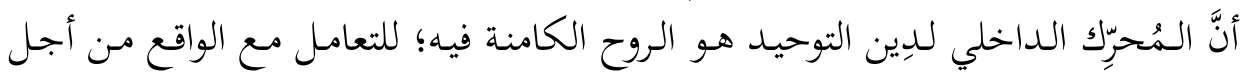
تغييره، ضمن مشروع يُحرِّر الذات والعالمَّ.

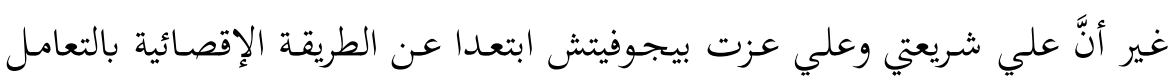

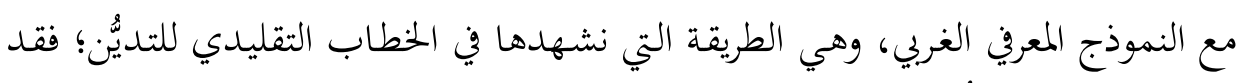

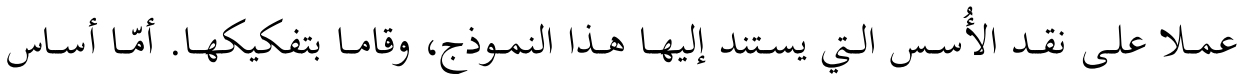

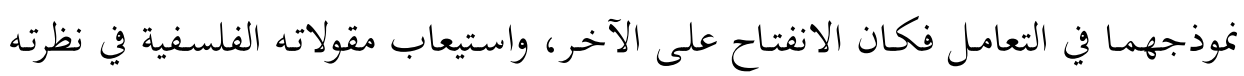
إلى الكون والإنسان، ثمَّ تحاوزها في سبيل بناء حضاري جديد. وبتلّلى هذا الأمر بوضوح

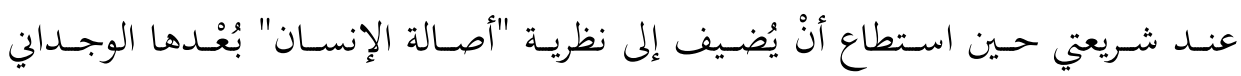

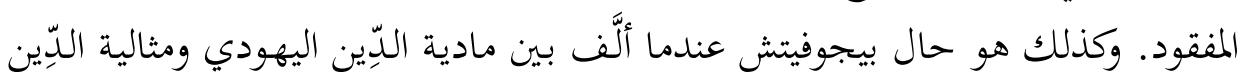

$$
\text { المسيحي، وجمع بينهما في الإسلام. }
$$

وقد انتهى البحث إلى أنَّ الوعي المعري بالنموذج التوحيدي، في نظرته إلى الإنسان،

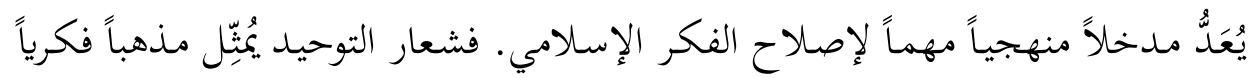

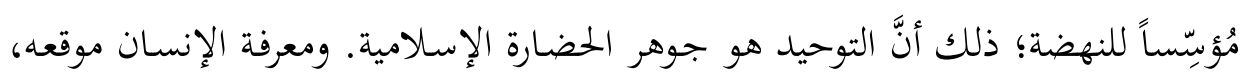

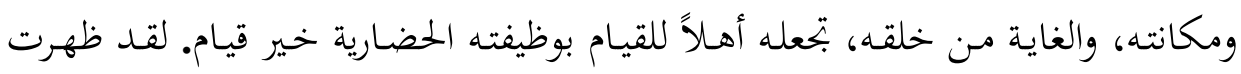

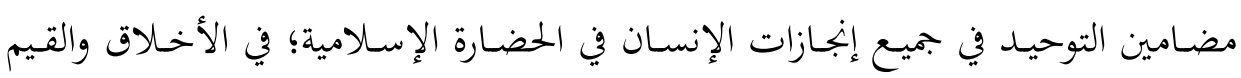

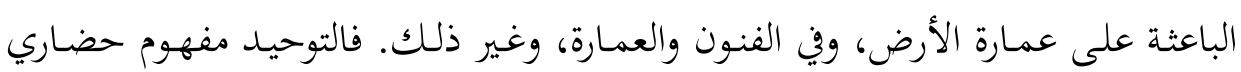

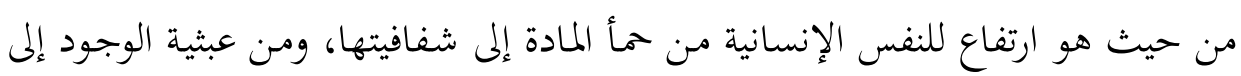


مقصديته، ومن جبرية الطبيعة إلى الحرية، ومن تاريخية الفعل إلى الفعل ذاته. ويُتوقَّع لهذه

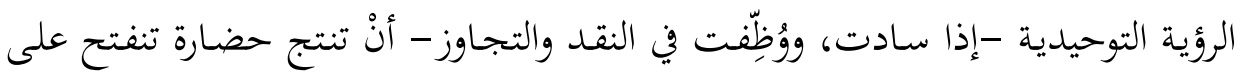

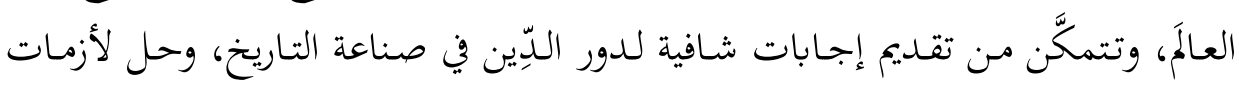

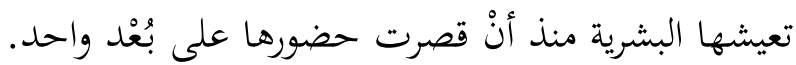

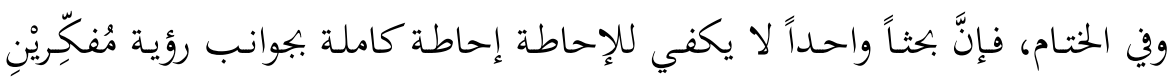

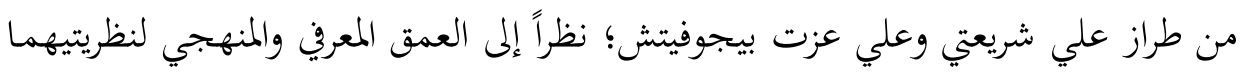

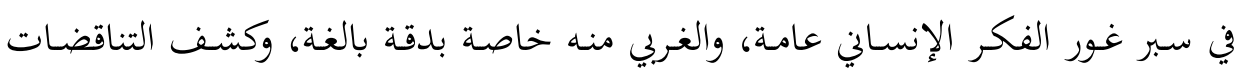

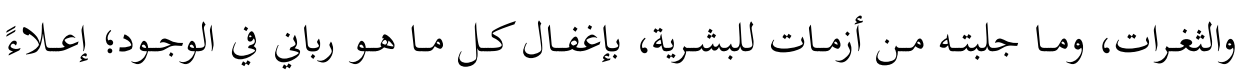
لشعار تقديس العقل، ورفعاً للواء الحرية الناقصة. 